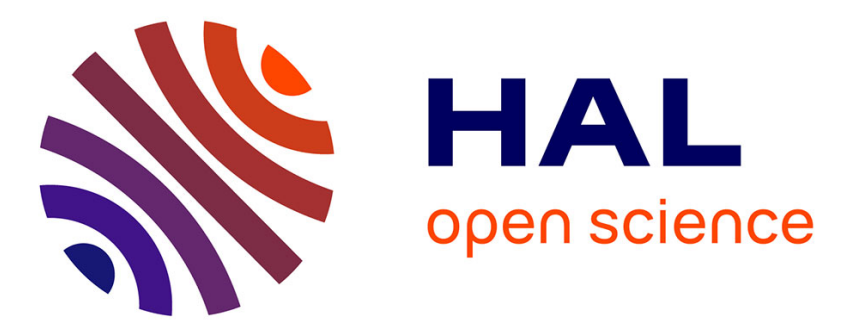

\title{
Maritime Silk Roads' Ornament Industries: Socio-political Practices and Cultural Transfers in the South China Sea
}

Bérénice Bellina

\section{- To cite this version:}

Bérénice Bellina. Maritime Silk Roads' Ornament Industries: Socio-political Practices and Cultural Transfers in the South China Sea. Cambridge Archaeological Journal, 2014, 24 (3), pp.345 - 377. 10.1017/S0959774314000547 . hal-02393453

\section{HAL Id: hal-02393453 \\ https://hal.science/hal-02393453}

Submitted on 7 Dec 2019

HAL is a multi-disciplinary open access archive for the deposit and dissemination of scientific research documents, whether they are published or not. The documents may come from teaching and research institutions in France or abroad, or from public or private research centers.
L'archive ouverte pluridisciplinaire HAL, est destinée au dépôt et à la diffusion de documents scientifiques de niveau recherche, publiés ou non, émanant des établissements d'enseignement et de recherche français ou étrangers, des laboratoires publics ou privés. 
Cambridge Archaeological Journal

http://journals.cambridge.org/CAJ

Additional services for Cambridge Archaeological Journal:

Email alerts: $\underline{\text { Click here }}$

Subscriptions: Click here

Commercial reprints: $\underline{\text { Click here }}$

Terms of use : $\underline{\text { Click here }}$

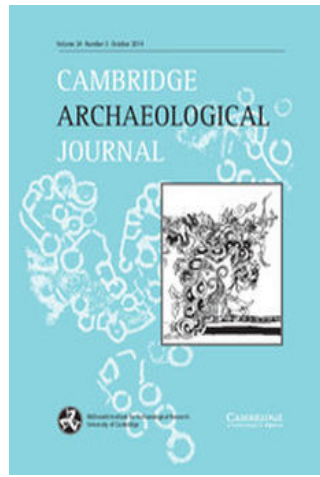

\section{Maritime Silk Roads' Ornament Industries: Socio-political Practices and Cultural Transfers in the South China Sea}

Bérénice Bellina

Cambridge Archaeological Journal / Volume 24 / Issue 03 / October 2014, pp 345 - 377

DOI: 10.1017/S0959774314000547, Published online: 03 November 2014

Link to this article: http://journals.cambridge.org/abstract S0959774314000547

How to cite this article:

Bérénice Bellina (2014). Maritime Silk Roads' Ornament Industries: Socio-political Practices and Cultural Transfers in the South China Sea. Cambridge Archaeological Journal, 24, pp 345-377 doi:10.1017/S0959774314000547

Request Permissions : $\underline{\text { Click here }}$ 


\title{
Maritime Silk Roads' Ornament Industries: Socio-political Practices and Cultural Transfers in the South China Sea
}

\author{
Bérénice Bellina
}

\begin{abstract}
The interlocking of the maritime basin network that took place with the development of the Maritime Silk Roads by the late first millennium вс led to major cultural transfers. This research investigates Southeast Asia's cultural integration and takes into consideration what I call a South China Sea network culture, a result of long-established and extensive connectivity of its populations. The assumption is that this cultural matrix also laid the ground for socio-political practices hypothesized to be at the core of identity building and cultural transfers. These issues are investigated through the technological analysis of hybrid ornament industries in a recently excavated early city-port of the South China Sea which developed with the Maritime Silk Roads that thrived from the fourth to the first centuries BC. This enclosed cosmopolitan settlement hosting populations from various Asian horizons was structured by socio-professional quarters. This node concentrated various craft centres where artisans of different origins made culturally hybrid products with what were then the most advanced technologies. The chronological sequence allows characterization of the evolution of these industries along with the socio-political strategies which they may have served and how otherness was handled in the construction of social identity.
\end{abstract}

During the last three decades, most disciplines in the humanities have experienced a profusion of globalization studies focusing on large-scale processes of social, economic and cultural integration. ${ }^{1}$ Two positions prevail. The first searched from prehistory to the modern era for processual continuities that could explain contemporary globalization. These researchers posit that globalization is the product of processes that took place outside Europe and which began well before the Middle Ages² (Beaujard 2005; 2012a, b; Beaujard et al. 2009). The second position holds that humanity has experienced several earlier socio-cultural processes crossing nations' boundaries. Through commercial transregional networks, societies have been interconnected since the remote past and the world has been 'globalized' for a very long time (Assayag 1998 , 216). Societies have never been isolated and cultures are intrinsically hybrid (Amselle 2000). This position emphasizes the need to replace them not only in long temporal and chronological perspectives, but also in spatial and relational perspectives (Assayag 1998). All of these positions grant a leading role to exchange networks, to nodes like port-cities and to the cosmopolitan societies that allowed a concentration and transfer of skills and innovations. Port-cities that developed with the Maritime Silk Roads are regarded as active agents of what is now considered previous globalization.

In this article, I want to highlight some sociopolitical processes at the core of one of these previous globalizations when, during the mid-first millennium вс, Southeast Asia integrated the Maritime Silk Roads, i.e. when Indian Ocean and the South China Sea networks interlocked. I shall do this through the technological analysis of ornament craft-industries that developed in the earliest port-city (known so far) of Khao Sam Kaeo (hereafter KSK) which emerged along the eastern coast of the Thai-Malay peninsula. Excavations from 2005 to 2009 have demonstrated its cosmopolitan configuration, a trait not only reflected 
in its urbanism (Bellina in press) but also in its industries. This polity appeared to be the earliest cosmopolitan enclosed urban settlement of the South China Sea area that thrived from the fourth to the first century BC (Bellina in press; Bellina et al. 2012; forthcoming; Bellina-Pryce 2008). It developed at a time when circumnavigation around the peninsula was not taking place and trans-isthmian routes were used, passing through series of river valleys, linking the Bay of Bengal and the South China Sea. At the exit of trans-peninsular routes, this node hosted foreign communities staying within quarters or compounds materialized by embankments, received commodities and cultural elements and produced hybrid cultural products that were redistributed from one basin to the other, thus contributing to the cultural process (Bellina 2011 ; in press). Its organization was based on socioprofessional quarters. The southern part of the settlement, the oldest core of the settlement, was occupied by local populations displaying South China Sea network cultural traits and by a few South Asian craftsmen producing what appear to be products made to order to suit their specific demand. The northern part of the site hosted groups coming from various Asian horizons: South Asian, Continental and insular Southeast Asian and Han Chinese; there were also working foreign craftsmen (Bellina et al. forthcoming). Possibly like the contemporary Sa-Huynh coastal prehistoric communities of Vietnam, those from KSK prefigured the pre-modern Indonesian 'pasisir'-type of societies and their entrepôts such as, to cite just a few, the Malays in Srivijaya and in Melaka, the Acehenese in Aceh in Sumatra, the Makassarese and Makasar in Sulawesi and the Sulu Sultanate of the Philippines (Bellina 2009; Glover 2009). 'Pasisir'-types of societies shared a trading orientation, were ethnically heterogeneous, outward-looking, dynamic, prompt to change and used lingua franca Austronesian languages such as Malay (Geertz 1963). For the first time, excavations have explored port-city workshops at KSK; those were of various industries (glass, stone, metal) and attested to the introduction of skilled exogenous technologies in Southeast Asia. This multi-ethnic settlement hosted hybrid industries associating artisans, technologies and styles of various Asian horizons producing products feeding different networks and serving different socio-political strategies of its actors. Some of the social groups, along with the specific products sought by them, can not yet be distinguished. Other specific products and their associated network, it is argued here, correspond to a trans-ethnic South China Sea network culture shared by communities located along the fringe of the South China Sea. Intensive as well as extensive connectivity within the
South China Sea, probably from the Neolithic (Bulbeck 2008; Gillis 2012; Hung et al. in press), led to the elaboration of a shared cultural matrix. It is argued here that it was driven by shared common sociopolitical practices that lasted even when, evolving in time, it adapted foreign vocabulary. It is this maritime network cultural matrix and its interplay with new foreign elements brought in with the Maritime Silk Roads that this article proposes to explore in the light of ornament industries that were made for its actors.

To do so, the article will begin with a very brief overview of the abundant historiography on the cultural exchange between South and Southeast Asia followed by a summary of the current view on the prehistoric Maritime Southeast Asia cultural matrix prior to and during its integration into Trans-Asiatic networks. I shall follow with a rationale for exploring technological systems to characterize socio-political and cultural configurations and their evolution in the context of broad trans-regional exchanges. This contextual preamble of this study will be followed by the technological analysis. The latter resulted in distinguishing four distinct technological groups (or technological traditions) whose on-site and regional spatial distribution allows interpretation in terms of social destination. Bringing together data from excavation, technological reconstruction and the sparse historical accounts relating to crafts and artisans, I will interpret the characteristics of the technological system evidenced at KSK to extrapolate what may have been its socio-political and economic context. Finally, I shall interpret what this industry tells us about the interplay between social identity construction and cultural transfers in the frame of the development of the maritime silk roads.

\section{Cultural exchange between South and Southeast Asia}

The KSK site and its hybrid industries bring new elements to the discussion of this long-debated cultural process, with its extensive bibliography (for example, to cite only a very few, Bertrand 2007; Cœdès 1968; De Casparis 1983; Kulke 1990; Mabbett 1977; 1997; Manguin et al. 2011; Ray 1994; Smith 1999; Vickery 1998; Wheatley 1983; Wisseman Christie 1984/5; 1990; 1995; Wolters 1999). Summarizing more than a century of scholarship, with the concept of Southeast Asia's 'Indianization' born during the colonial period, an externalist view that emphasized South Asian external influences with the diffusion in concentric circles of a set of religious thoughts and practices has prevailed. In reaction to this approach an 


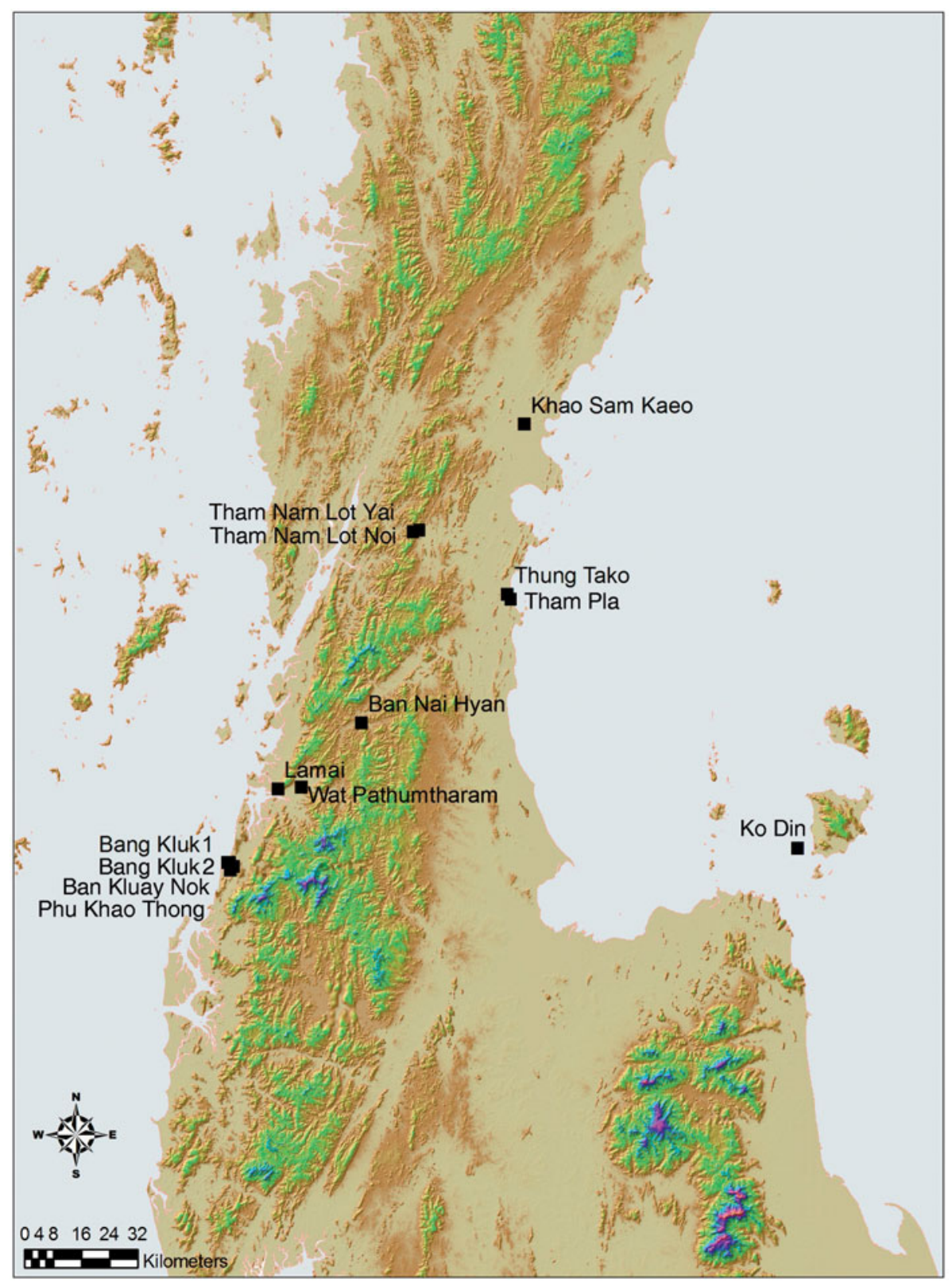

Figure 1. Regional map showing places referred to in the text.

'internalist' or 'autonomist' paradigm emerged (Benda 1962; Smail 1962) which, in turn, emphasized endogenous factors of cultural, social and political change in Southeast Asia. The region was no longer conceived of as a passive recipient, but rather as a politically autonomous centre able to generate its own specific social, religious and political organization, which survived through adjustments to later external impositions. The 1980s opened the avenue to more mixed paradigms, between the 'externalist' and the 'internalist' historical trends, emphasizing innova- tions resulting from the local adoption and adaptation of Indian models: the 'localization' of Wolters (1982) or the 'vernacularization' of Pollock (2000; 2006). However this position sometimes seems to experience difficulties in remaining balanced, as illustrated in the case of the formation of the maritime state of Funan at Oc Eo in the Mekong delta (Fig. 1) and a trend to disconnect, chronologically, this emergence from the cultural exchange process with South Asia in order to avoid echoing old diffusionist 'Indianization' positions (Bourdonneau 2010). 
In Southeast Asia, the emergence of complex polities involved in long-distance exchange, whether called states or city-states, concomitant with or following the establishment of the Maritime Silk Roads from the last centuries Bс has often been analysed as a by-product the 'Indianization' of Southeast Asia (Bronson 1977; Cœdès 1968; Glover 2000; Hall 1982; 1985; Manguin 2000; 2004; Wisseman Christie 1984/5; 1990; 1995). Understanding of these early polities has been greatly improved over recent decades through excavations of settlements (Fig. 1), including Oc Eo and Angkor Borei in the Mekong delta part of the Funanese polity (Manguin 2004; Manguin \& Khai 2000; Stark 1998; 2006; Stark \& Souath 2001; Stark et al. 1999), Go Cam, a site of the polity of Linyi, Tra Kieu the ancient capital of Champa in central Vietnam (Yamagata 1997; 2007; Yamagata \& Glover 1994), Tarumanagara and Batujaya in West Java (Manguin \& Agustinjanto 2006; 2011), and KSK and Phu Khao Thong in the Thai-Malay Peninsula (Bellina in press; Bellina et al. forthcoming; Bellina-Pryce 2008; Bellina-Pryce \& Silapanth 2008). However, the extent to which they also built upon earlier established socio-political patterns is of major concern. Indeed, in Maritime Southeast Asia, a sense of historical continuity prevails amongst historians even if this continuity was hypothesized at a time when little was known about the late prehistoric communities (Andaya 2008; Manguin 2000; Wisseman Christie 1995). Prehistoric coastal communities in the Malacca Straits and along the southern shores of the Java Sea (Malayo-Polynesian-speaking populations), who witnessed the emergence of early states, had previously been tied into several overlapping prehistoric maritime trade networks and had come to share a number of cultural traits, in particular basic political concepts brought in during the Neolithic period. The region owed most of its economic development to demands from the South Asian or Chinese whilst its political development resulted mainly from the desire to control this trade (Wisseman Christie 1995). Inspired by later historical situations, peer-polity interaction between the late prehistoric competing polities has been hypothesized as one likely driving force for the transmission and elaboration of political models later found in historical states of the region (Wisseman Christie 1995, 250).

In this context, it appears clearly that in order to understand the cultural interactions between the Indian Ocean and the South China Sea, one must thus take into consideration this earlier prehistoric regional network and, to the degree that they can be reconstructed, the socio-political practices of its populations from the dawn of the first millennium вс.

\section{Prehistoric cultural matrix and exchange within the Maritime Southeast Asia}

The early periods of connectivity across the South China Sea have long been known through tenuous archaeological evidence and biological and linguistic reconstructions (Bellwood 2011). The last decade has witnessed increasing interest in late prehistoric and early historic exchange documented through industries such as siliceous stone, (Bellina 2001; 2003; 2007; Theunissen 2007; Theunissen et al. 2000) and, with ever-increasing use of physico-chemical analysis, glass (Dussubieux 2001; Dussubieux and Gratuze 2010), metal (Bennett 2008; Bennett \& Glover 1992; Hendrickson et al. in press; Murillo-Barroso et al. 2010; Pryce et al. 2011), and nephrite (Hung \& Bellwood 2010; Hung et al. 2007). They have unravelled major insights on patterns of long-distance distribution as early as the last centuries $\mathrm{BC}$ and addressed the means by which complex technologies were transmitted. Each of these specific studies provided hard evidence for a pre-existing prehistoric exchange network in the South China Sea. From peninsular Thailand to coastal Vietnam and the Philippines, several populations came to adopt a similar set of exotic valuables some of which showed specific technological and stylistic similarities. This included nephrite lingling'o, 'interrupted rings' (a type of ornament whose basic form is a ring with a slit in one side to fit the pierced earlobe), doubled-headed ornaments, some specific types of carnelian and agate beads, some glass ornaments and some metallic vessels (Bellina 2001; 2007; Hung \& Bellwood 2010; Hung et al. in press) (Fig. 2). This late prehistoric South China Sea network, attested from the mid-first millennium BC, overlaps some of the connections observed earlier mainly through what W. Solheim had labelled the 'Sa HuynhKalanay pottery complex', a network he subsequently called the 'Nusantao Maritime Trading and Communication Network' (NMTCM) (Solheim 2000; 2006). These similarities may be interpreted as manifestations of a shared cultural idiom, the result of sustained interactions between diverse populations situated on the fringe of the South China Sea that started from the Neolithic (Bulbeck 2008) and which ended over time producing cultural similarities and Malay as a lingua franca (Bellina in press; Hung \& Bellwood 2010; Solheim 2006).

Stylistic and formal similarities across a region have long been perceived as resulting from a network of interaction (Stark 1998; Wobst 1977). When this common distribution concerns highly similar prestige goods across extensive regions, a phenomenon observed in various chiefdoms in Central America, 


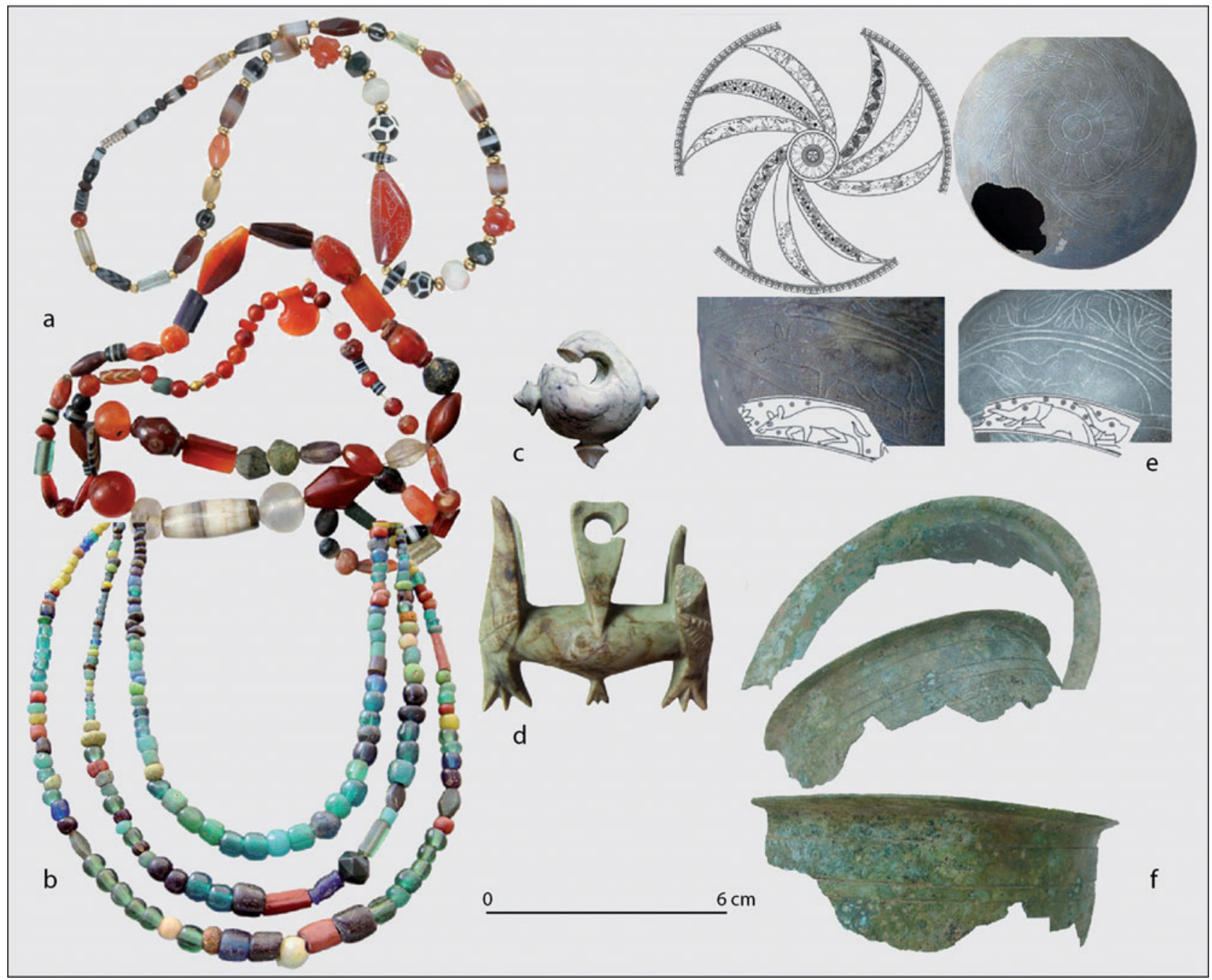

Figure 2. Several populations came to adopt similar sets of exotic valuables some of which showed specific technological and stylistic similarities such as the nephrite lingling'o, doubled-headed ornaments, some specific types of carnelian and agate beads, some glass ornaments and some metallic vessels.

in Hawaii (Earle 1990; Hantman \& Plog 1982) and in the Philippines (Bacus 2003; Junker 1990; 1993; 1999), studies put forward the concept of a set of inter-polity symbolic system expressing elite group alliances and shared identity.

\section{Cultural exchange through analysis of technological systems}

To tackle these issues in the absence of textual evidence, it is argued here that one of the best means to explore the cultural matrix and its reactivity to foreign elements is a technological study of industrial production systems that emerged in regional nodes in tune with the Maritime Silk Roads and their evolution through time. This is what KSK investigation tackles for the first time. Other comparable sites had long been known to have hosted industries feeding various networks. As an illustration, Oc Eo in the Mekong Delta furnished evidence for the working of several industries such as metal ornaments and vessels, stone and glass ornament production amongst other (Malleret 1959; 1960; 1962; 1963). In other cases, well-known industries have long been recognized without being associated with an identified polity, such as in the case of Khlong Thom (Khuan Lukpad, province of Krabi) bead production in peninsular Thailand (Bronson 1990; Veraprasert 1992). Most of these industries used imported raw material and involved complex exogenous technologies. However, whether some of the goods found there were partly imported and/or made locally and the social groups for which they 
were made remained largely unknown until only recently. Studies looked at these products as indicators of exchange, and focused on the consumption and not the production system (the producers included). The existence of these by-products of trade was justified by their use as political currencies to direct inter-polity exchange (Junker 1999) and to cement networks of loyalties between similarly complex and developed socio-political systems (Wolters 1999) or between less complex inland groups providing the raw materials and goods needed for long-distance trade (Bronson 1977; Wisseman Christie 1990). The groups' specific values and beliefs expressed by the technological choices (Costin 2001; Lemonnier 1993) made during the manufacture and use of the ornaments was not addressed, nor was the extent to which artisans contributed to producing social and cultural forms. The social life of these objects, their potential change of meaning in a pluri-ethnic context (Appadurai 1986), has not been considered nor have the different stages of their life from production to successive distribution networks (Bromberger \& Chelvallier 1998) from production to consumption. By only considering the end of the production line, reconstructions in South and Southeast Asian archaeology have mainly considered ornaments as economic commodities and given little consideration to the socio-political and cultural dimensions that this craft encapsulates.

\section{Study of the technological system}

\section{Data and methods}

The body of data considered here consists of 435 samples from excavations (174), survey (21) and local collections (240). As far as possible, the latter were semicontextualized a posteriori by recording the location with local villagers using a GPS unit. The level of certainty of their context was ranked and taken into consideration in subsequent spatial analysis (Malakie LaClair \& Bevan forthcoming).

Each specimen has been recorded describing its raw material, its manufacturing technologies including the perforating and polishing technologies and style, characterized by the morphometry, i.e. the relationship between morphologies and their dimensions. ${ }^{3}$ The polishing technologies were characterized based both on the microscopic traces on the surface left by the tools used and also scores attributed to the ways in which they were finished and executed. Three types of polishing technique have been used: bead polisher (often a stone with several aligned grooves), rotary polisher and in a container (possibly a leather bag). A single technique can be used for every stage of the polishing (abrasion, polishing and final pol- ishing providing the lustre) or different techniques can be combined according to the morphology and the quality sought. ${ }^{4}$ Some fashioning and polishing techniques require more skill (and hence duration of apprenticeship) and are more time-consuming than others. As an illustration, use of the indirect percussion knapping technique to fashion rough-outs associated with rotary grinding-stone polishing techniques implies skilled craftsmen (in India, knapping and polishing stages are operated by different specialists) and more time dedicated to the production of the artefact. In contrast, use of leather bags (within which several beads are placed together along with abrasive powder and shaken for several hours) at each stage of the chaîne opératoire, i.e. from shaping the beads, instead of knapping, and for polishing and final polishing, is less time-consuming, requires no skill and the resulting final product is less symmetric (and thus never facetted), with impacts on the surface and lower quality. Several techniques can be used at each stage, possibly leaving diagnostic traces, and several techniques can be combined according to the shape (facetted or not) and the quality sought. Besides the fashioning and the polishing techniques, the quality of the final product and hence the skill involved, are also evaluated by the perforation techniques, the mastering of the heating of the raw material and finally by the quality of the raw material. It is the combination of all these technological criteria that allows us to characterize the type of production.

Ethno-archaeological research (Roux 2000) has provided the frame of reference for the techniques and corresponding skill. The rotary grinding-stone technique, as practised in late twentieth century in Cambay (Fig. 3, image 1), produces regular parallel grooves of different depth depending on the polishing stage (Fig. 1, images 2 to 4): abrasion (Fig. 1, image 2), polishing (Fig. 1, image 3) and final polishing (Fig. 1, image 4). The methodology consists of comparing archaeological bead-surface traces with traces from the frame of reference. As an illustration, the identification of groups of linear polishing grooves on the surface of an archaeological bead from KSK (Fig. 1, images 5 and 6) leads me suggest the use of a rotary grinding stone for different stages of polishing. Similar but more discrete traces can be observed on the surfaces of a facetted flat lozenge-shaped bead from KSK (Fig. 1, images 7 and 8 ) and of a spherical bead (Fig. 1, images 9 and 10); in the latter case, due to the roundness of the bead, the pressure of the rotary grinding stone against it generates small polishing-facets.

In contrast, the use of leather bag produces impacts corresponding to deep conchoidal pits and lines of fractures more or less pronounced according to the 

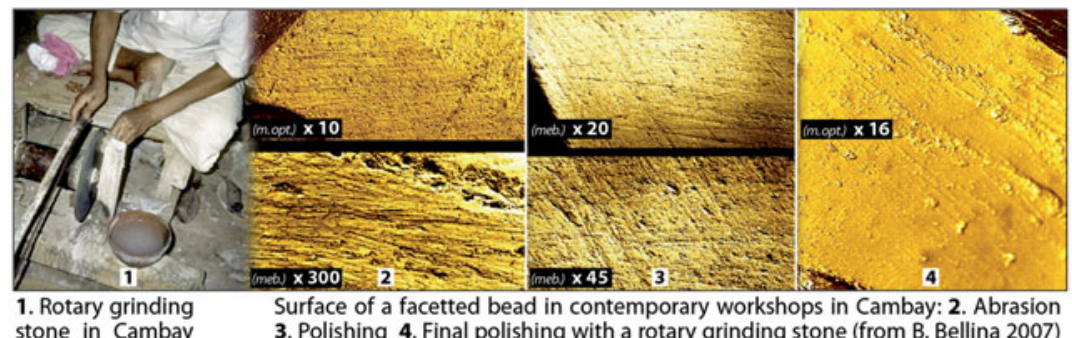

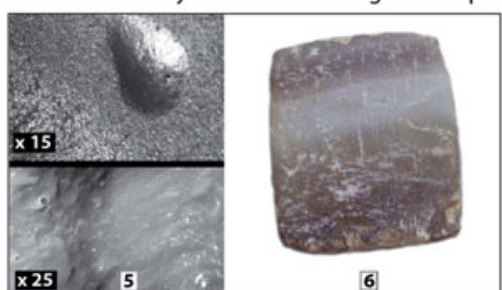

5. Surface of a roughout of a facetted bead from KSK whose polishing was done with a rotary grinding stone and displaying knapping remains 6 . Facetted bead from KSK whose polishing was done with a rotary grinding stone

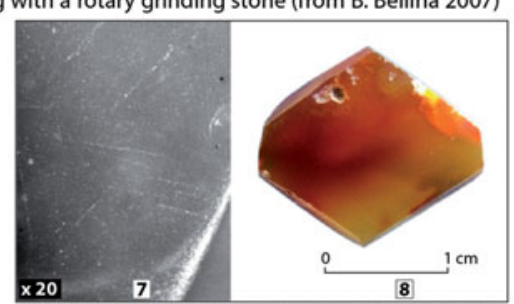

7. Surface of a facetted bead from KSK polished and finally polished with a rotary grinding stone 8. Facetted bead from KSK polished and finally polished with a rotary grinding stone

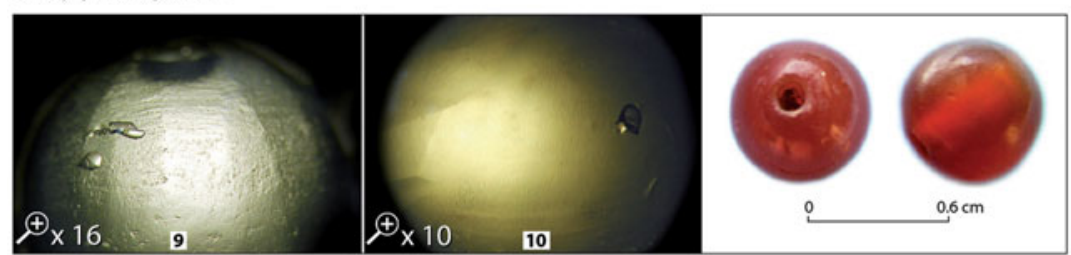

9. Polishing 10. Final polishing of a spherical bead with a rotary grinding stone

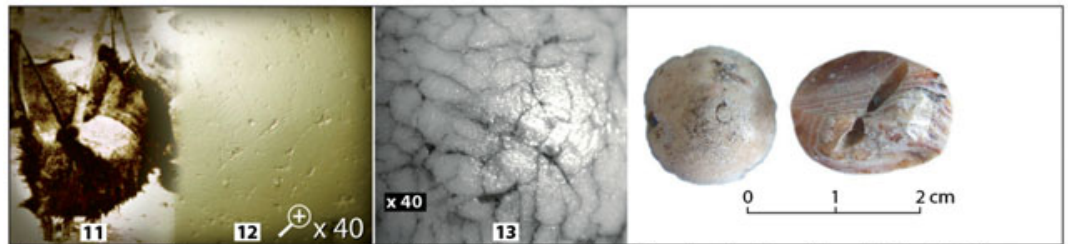

11. Ethnographic leather bag 12. Spherical bead finally polished in a leather bag (from Bellina 2007) 13. Spherical bead from KSK (waste of production), polishing and final polishing in a bag

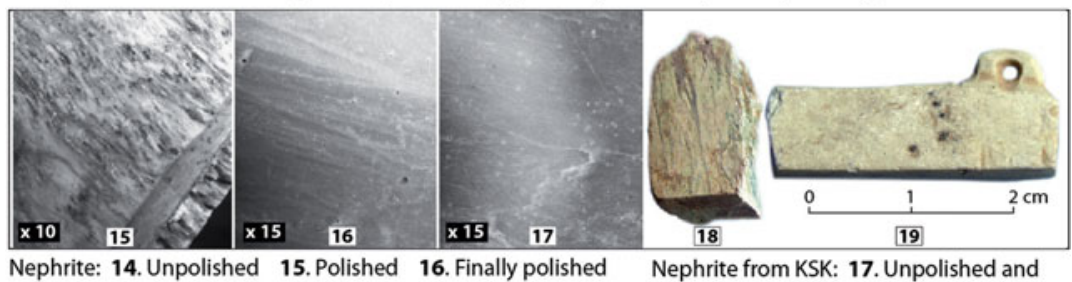

$\begin{array}{lll}\text { Nephrite: } \mathbf{1 4} \text {. Unpolished } \mathbf{1 5} \text {. Polished } \quad \text { 16. Finally polished } & \text { Nephrite from KSK: 17. Un } \\ & \text { 18. Finally polished object }\end{array}$

Figure 3. Some examples of the polishing marks, associated with the different techniques, groups of morphologies (spherical beads are not polished necessarily with the same tools as the facetted ones) and the qualities obtained. First are images from ethno-archaeological research (Roux 2000) showing the technologies used at different stages of the production line and the resulting surface. These photos are followed by photos of the surface of a bead from KSK which exhibits similar or different types of traces, and a macroscopic photo of the specimen. The first photos show the use of the time-consuming rotary grinding stone technique at each stage for facetted beads in Cambay. The following photos present the surface of beads displaying comparable traces, therefore leading me to interpret the use of similar techniques. A second example is that of spherical bead being polished and finally polished with a rotary grinding stone, generating small polishing facets, as well as the surface of a bead finally polished in a leather bag. In comparison is given the photo of the surface of an unfinished spherical bead from Hill 4 at KSK (of the Group 4, see text), polished in a leather bag and characterized by deep fracture lines. The latest photograph is taken from this bead. Finally, the last photos are micrographs taken of an unpolished block, a polished piece and a finally polished object in nephrite. The macroscopic photos show the corresponding archaeological piece. 
Table 1. Table of scores used in the assessment of the quality of shaping and abrasion of carnelian.

\begin{tabular}{|l|c|c|c|c|}
\hline Scores & $\begin{array}{c}\text { Carnelian } \\
\text { quality }\end{array}$ & Symmetry & Surface & Lustre \\
\hline Not applicable & 0 & 0 & 0 & 0 \\
\hline Good & 1 & 1 & 1 & 1 \\
\hline Average & 2 & 2 & 2 & 2 \\
\hline Mediocre & 3 & 3 & 3 & 3 \\
\hline
\end{tabular}

stages the bead went through (Fig. 1,image 11). As an illustration, the surface of a waste product of production, a spherical bead from hill 4 at KSK (Fig. 1, image 13 , belonging to Group 4, see below in the text), shows deep fracture lines indicating that it had been polished and finely polished in a leather bag (Fig. 1, image 13).

In order to evaluate the quality of the product, besides considering the technologies implemented (as opposed to aesthetic criteria), I use scores. I assess the quality of the finish according to the state of the beads' surface. This varies depending on angularity and shine. The different finishing operations should make the angularities resulting from shaping disappear and give a brilliant aspect to the bead. The quality of the shine comes from the polishing process. Finishing quality was estimated according to the quality of the shaping, the abrasion, and the polishing. In order to assess the quality of shaping and abrasion, cutting residues (hollows and angularities have been quantified by giving a mark of 1,2 or 3); the deeper and more numerous the angularities the more the shaping and abrasion quality is considered mediocre and the higher the mark. Consequently, the closer the average is to 1 , the better the quality of shaping and abrasion. In order to assess the quality of shine - or brilliance a mark of one to three has been attributed; if the surface is dull the mark is 3 . Consequently, the closer the average to 1 , the better the shine. Obviously only the beads which have been polished (finely polished, i.e. finished) are taken into account. Quality of execution was assessed by the piece's symmetry. It allows the assessment of shaping and abrasion quality. The quality of execution has been quantified with a mark. A mark of 1 indicates that the piece is symmetric, a mark of 2 that it is asymmetric, and a mark of 3 , very asymmetric.

One of the challenges consists of distinguishing traces made during the manufacturing process from those produced by their use in the past or postdepositional process. In the first case, there is some characteristic evidence such as deteriorated surfaces surrounding the perforation whole, a deterioration produced by the shock impact between beads when worn on a string. Post-depositional deterioration of the surface is not easy due to the absence of ethnoarchaeological experiments. I have observed some deterioration that I attributed to post-deposition, such as whitening of the surface. I was inclined to suggest post-depositional deterioration because, in comparison to the rest of the corpus' different context and noting the presence or absence of fractures, the latter might instead suggest a heating accident.

Khao Sam Kaeo has yielded evidence for each stage of the production sequence: unheated and heated raw material, rough-outs, preforms, unperforated and unpolished ornaments, wasters and a few pieces interpreted as evidence of apprenticeship. Both the excavated and looted assemblages comprise evidence of production and finished ornaments. For the statistics, a distinction was made between 'definite' and 'possible' evidence; 'possible evidence' consists of fragments of ornaments likely broken during the manufacturing process but for which certainty cannot be ascribed.

To sum up, three groups of criteria were used to characterize the beads:

1. technological criteria, allowing reconstruction of the production line (raw material, skill, polishing techniques) and evaluation of the quality,

2. stylistic criteria, morphometry (combination of morphology and dimension), and

\section{3. location.}

Of the 435 pieces studied, 124 provide definite evidence of production ( 81 from excavation), 42 possible evidence ( 24 from excavation), 14 indeterminate (six from excavation) and 253 finished artefacts (56 from excavation). In total, almost half of the identified material (excluding the indeterminate category) represents evidence of production, therefore confirming the importance of the hard stone ornaments manufacturing industry on the site.

\section{Results: The four technological groups}

The characterization of the hard stone assemblage, according to the criteria described above, resulted in identifying four groups (Fig. 5). These display different technological and stylistic characteristics. I interpret these groups as distinct types of production answering specific demands from distinct social groups or similar groups whose ideational world evolved through time. The different production and distribution network which they represent can be interpreted in socio-political and cultural terms.

Group 1: The South China Sea siliceous type of production This type of production combines traditional Indian high-quality raw material and highly skilled Indian 

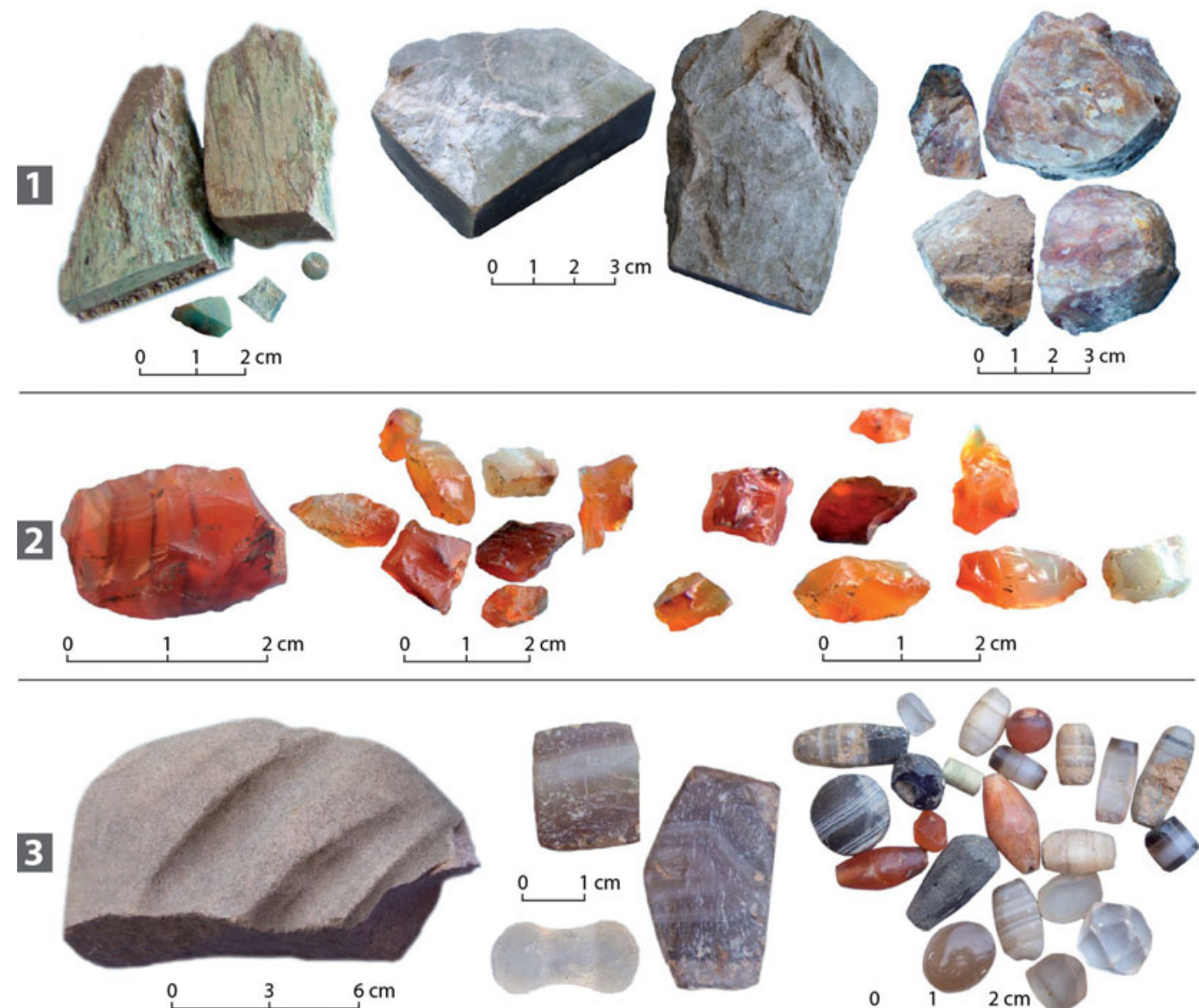

$2 \mathrm{~cm}$
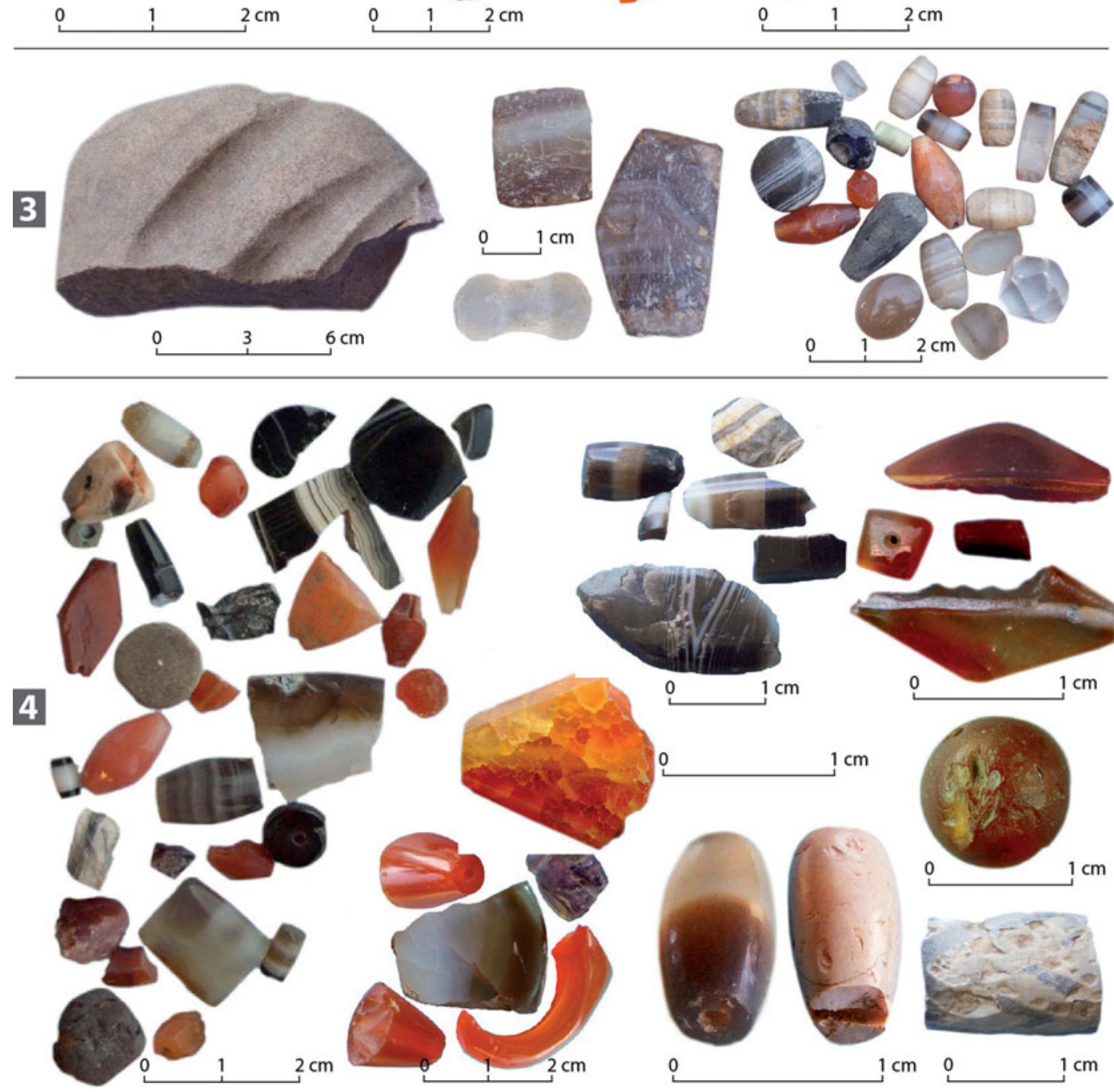

Figure 4. Production evidence from raw materials, bead polishing and production wastes. 


\section{The Four Hard Stone Groups}

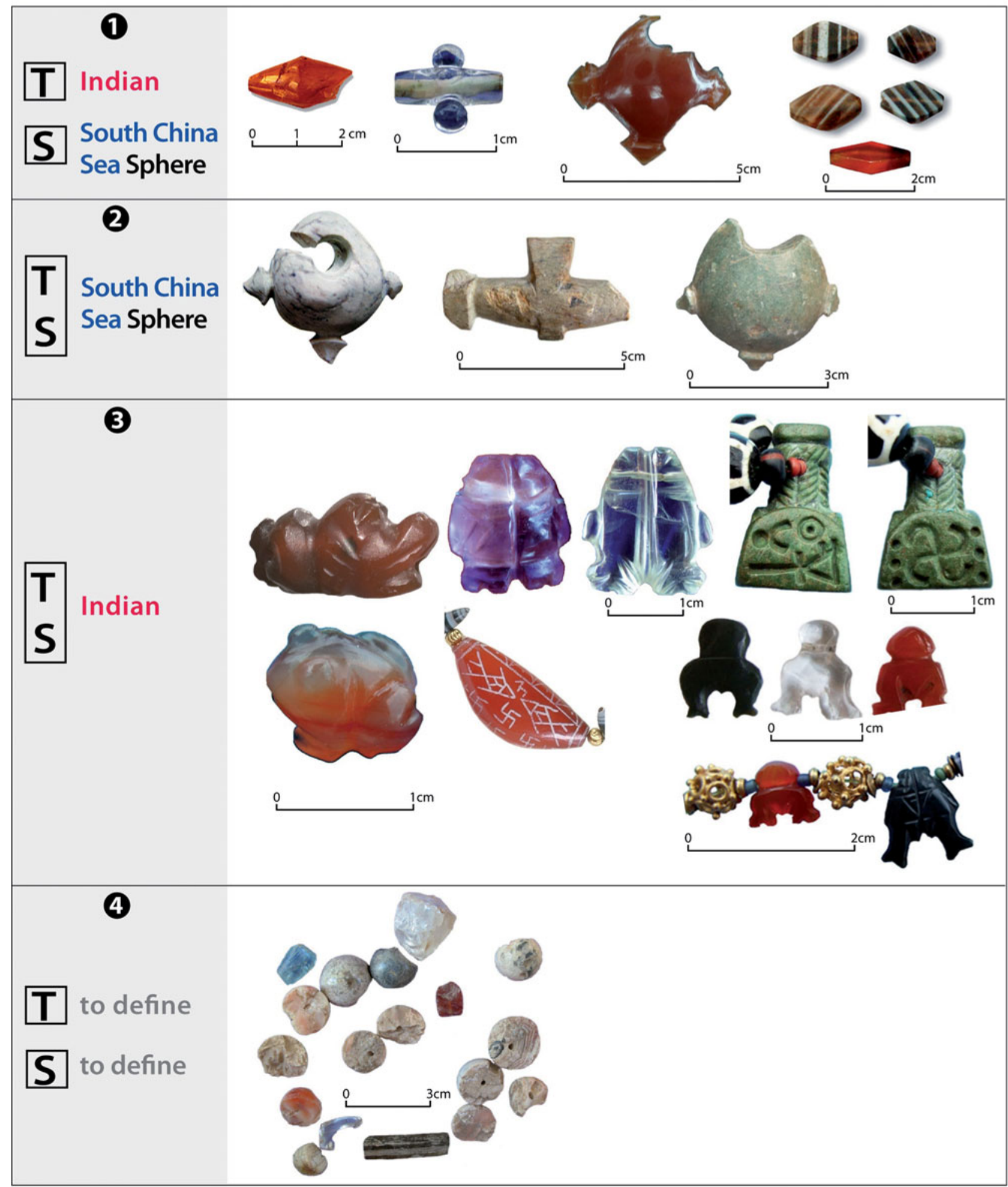

$\mathbf{T}$ Techniques $\mathbf{S}$ Style

Figure 5. The four technological groups identified at Khao Sam Kaeo. 
technologies with South China Sea-related style and is located in the southern part of the site. The assemblage consists of 128 beads, including 37 with definite evidence of production and 17 more with possible evidence.

Raw materials: The raw materials involve traditional South Asian good-quality carnelian, agate, jasper and amethyst, more rarely garnet and potentially rock crystal (this raw material is widely available in Southeast Asia). Carnelian is the most frequently used raw material. More than $80 \%$ of these artefacts are carnelian, with 15 or fewer pieces of each of the other materials represented (agate 15; amethyst 1; possible amber 2; carnelian 104; rock crystal: 4; undetermined stone 1 ).

Techniques: Techniques correspond to highly skilled South Asian technologies evidenced at every stage of the production line. The perforation diameter of Group 1 is very small with a hole of mean diameter $1 \mathrm{~mm}$ (range: 0.60 to $1.50 \mathrm{~mm}$ ). Regarding manufacturing techniques, ornaments are almost exclusively made using a rotary grinding stone at every stage of the production line, i.e. for abrasion (118 against 5 undetermined and 5 'leather' bags) and the polishing and final polishing (106 against 11 'leather' bags and 11 undetermined). These finishing techniques are the most time-consuming.

Quality: Artefacts belonging to Group 1 have high-quality scores. As shown in Table 2 and represented in the cumulative graphs (Diagram 1), more than half the specimens are ranked as very good in terms of symmetry, surface, lustre and carnelian quality. Specimens not ranked (or ranked 0 ) are production waste.

Style: The range of shapes is small, 17 in total (Fig. 6), characterized by complex types based on a double pyramid morphology (with a square, heptagonal, hexagonal, or octagonal section) with flat hexagonal-shaped beads dominating. It also includes other complex types such as octahedra and dodecahedra. Amongst the ellipsoid morphologies, proportionally less frequent, the ellipse with central knobs is noticeable. Another peculiar specimen is a carnelian 'lingling' $\mathrm{o}^{\prime}$. One fragment of each of a pendent and a double pyramid are counted but are not represented in the Table 2.

Location: The location of this group is well delimited. Manufacturing evidence for this type of production has been found at the bottom of Hill 2 (TP1, 7, 29, 41, 129, 130 and 132). Derived from excavated evidence of production I suggest that, based on the concentration of evidence across the built structures interpreted as workshops, the scale of production was that of a household. The size of these structures is
Table 2. Qualitative scores attributed to ornaments belonging to each Group.

\begin{tabular}{|c|c|c|c|c|c|}
\hline \multicolumn{4}{|c|}{ Group 1} & \multicolumn{2}{|l|}{ Carnelian } \\
\hline Quality & Symmetry & Surface & Lustre & quality & Total \\
\hline 0 & 28 & 13 & 13 & 20 & 74 \\
\hline 1 & 64 & 80 & 64 & 53 & 261 \\
\hline 2 & 24 & 24 & 25 & 30 & 103 \\
\hline 3 & 12 & 11 & 26 & 2 & 51 \\
\hline Total & 128 & 128 & 128 & 105 & 489 \\
\hline \multicolumn{6}{|c|}{ Group 2} \\
\hline Quality & Symmetry & Surface & Lustre & $\begin{array}{c}\text { Carnelian } \\
\text { quality }\end{array}$ & Total \\
\hline 0 & 22 & 20 & 20 & 0 & 62 \\
\hline 1 & 4 & 4 & 1 & 0 & 9 \\
\hline 2 & 1 & 2 & 5 & 0 & 8 \\
\hline 3 & 0 & 1 & 1 & 0 & 2 \\
\hline Total & 27 & 27 & 27 & 0 & 81 \\
\hline \multicolumn{6}{|c|}{ Group 3} \\
\hline Quality & Symmetry & Surface & Lustre & $\begin{array}{c}\text { Carnelian } \\
\text { quality }\end{array}$ & Total \\
\hline 0 & 15 & 5 & 8 & 20 & 48 \\
\hline 1 & 106 & 96 & 36 & 21 & 259 \\
\hline 2 & 45 & 60 & 66 & 11 & 182 \\
\hline 3 & 3 & 8 & 59 & 3 & 73 \\
\hline Total & 169 & 169 & 169 & 55 & 562 \\
\hline \multicolumn{6}{|c|}{ Group 4} \\
\hline Quality & Symmetry & Surface & Lustre & $\begin{array}{c}\text { Carnelian } \\
\text { quality }\end{array}$ & Total \\
\hline 0 & 1 & 1 & 4 & 0 & 6 \\
\hline 1 & 3 & 3 & 3 & 0 & 9 \\
\hline 2 & 4 & 3 & 1 & 0 & 8 \\
\hline 3 & 0 & 1 & 0 & 0 & 1 \\
\hline Total & 8 & 8 & 8 & 0 & 24 \\
\hline
\end{tabular}

similar to those used for habitation. Some of the evidence may suggest the presence of an apprentice: production waste concentrated in the western area of two levels corresponds to built floors. The waste represents the various mistakes that occurred at different stages of the production. The usual waste associated with stone bead production such as flakes and some finished beads was found below and above these layers. The amount of waste recovered (c. 20 specimens) suggests production or apprenticeship at only individual household scale.

The on-site distribution of Group 1 seems to be concentrated in the southern part of the settlement, on Hills 1 and 2 (Fig. 8). The distribution of Group 1 artefacts across the site differs significantly from what would be expected to occur by chance at $p=0.05$. The distribution was tested against that of all hard stone artefacts $(p=5.29)$, all artefacts $(p=7.05)$, and the 
Bérénice Bellina

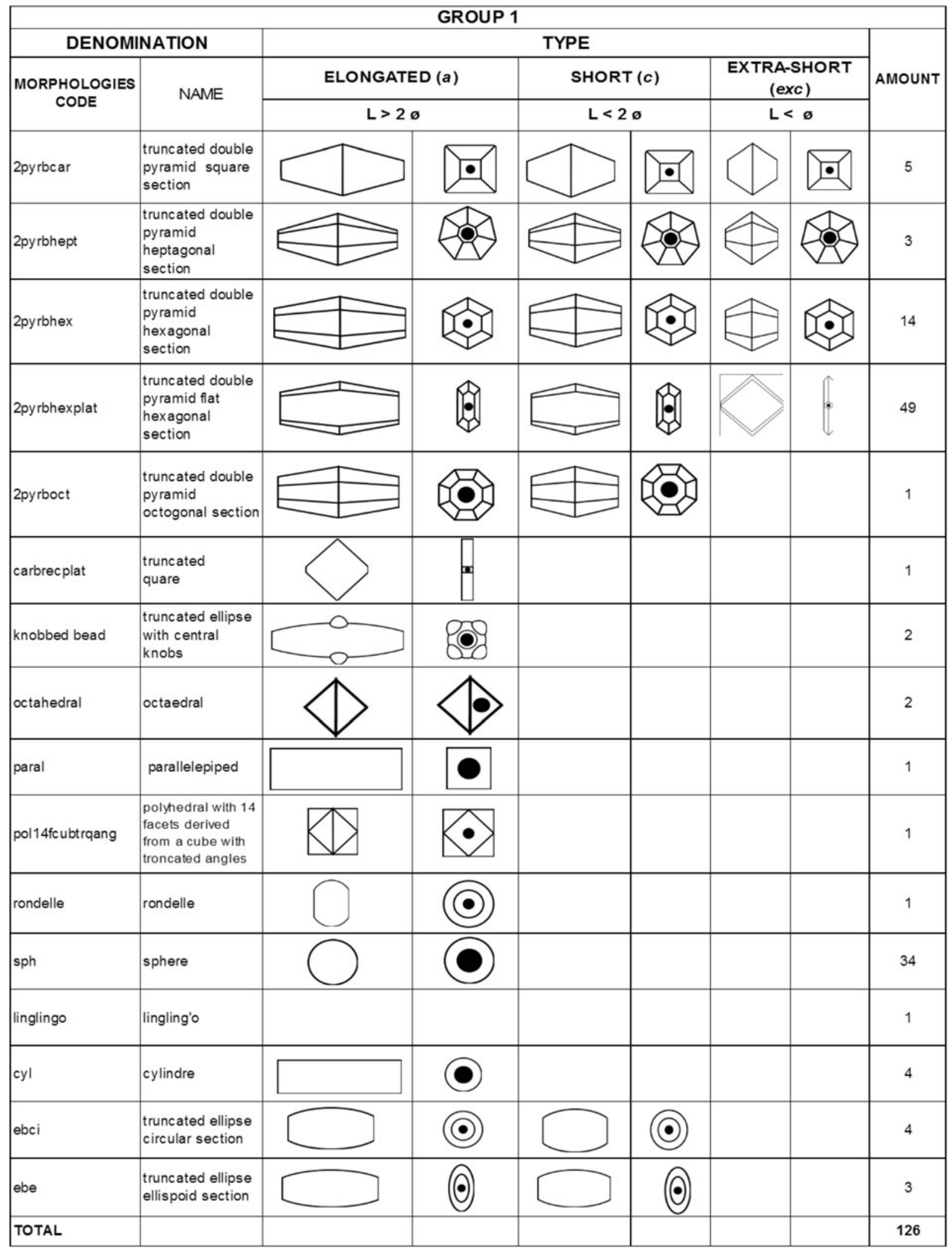

Figure 6. Group 1 morphologies. 

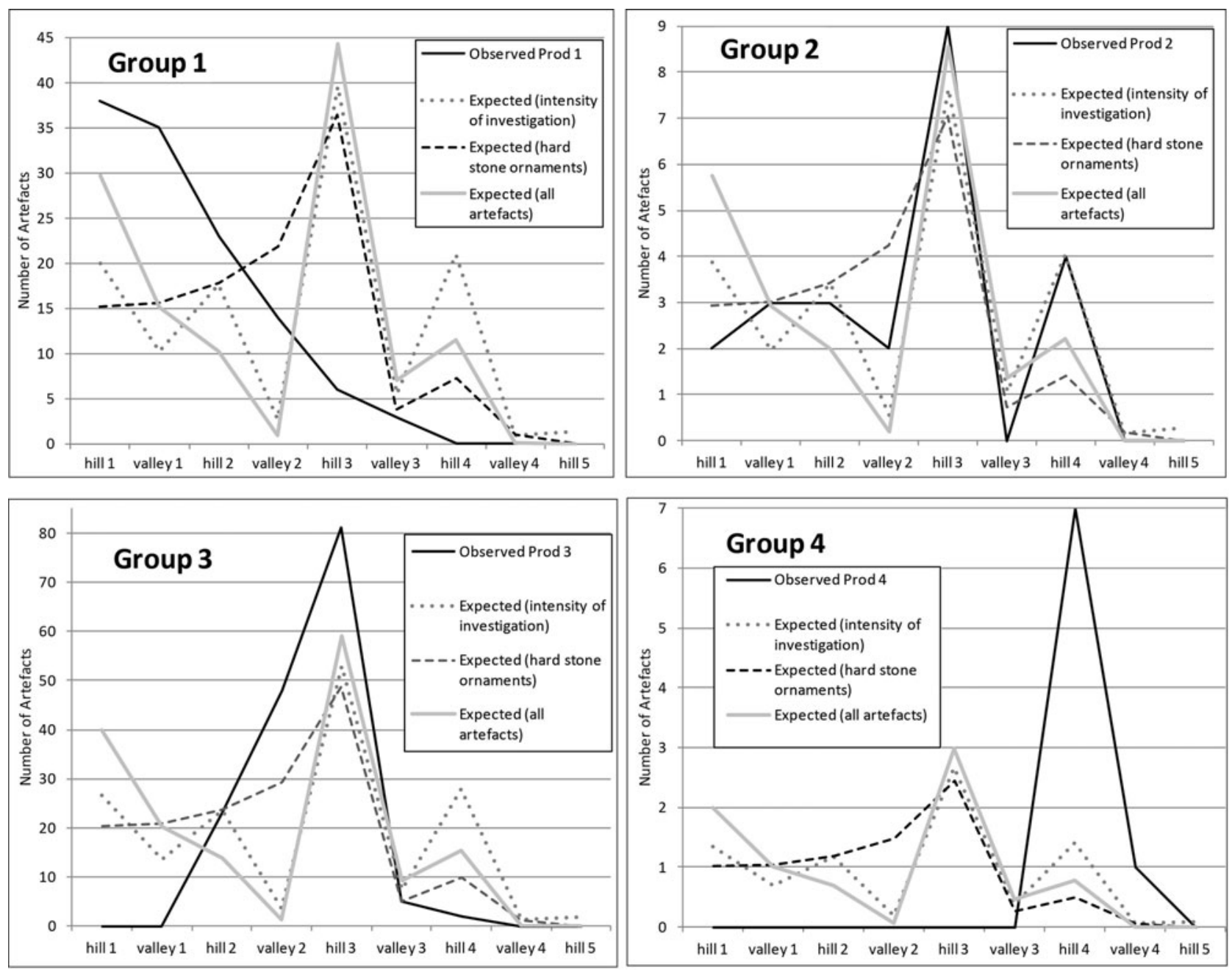

Figure 7. Graphs showing the observed and expected presence of each group on the site.

proxy measure for intensity of investigation (number of 'locations'; $p=7.93$ ). The southern half of the site was found to contain significantly more production type I artefacts than expected in all cases.

Group 2: The South China Sea jadeite type of production Group 2 comprises South China Sea-related raw material such as nephrite and mica, and their associated techniques and style. The assemblage is very small, consisting of only six ornaments (two lingling' $\mathrm{O}$ and two double-headed ornaments), two bracelets and 19 pieces of evidence linked to production (three fragments and 16 fragments of worked raw material). For this reason nephrite and mica raw material and production fragments were included in this group despite not having been included in any of the others.

Raw materials: The raw materials used are nephrite (jade) and mica, which are traditional raw materials used during the Neolithic in China, North Vietnam and East Asia (Taiwan, the Philippines). Several samples from Khao Sam Kaeo were sent to Yoshiyuki Iizuka at the Institute of Earth Sciences, Academia Sinica in Taiwan for compositional analysis using electron probe micro-analysis. Yoshiyuki lizuka and Hsiao-Chun Hung (Department of Archaeology and Natural History, Australian National University, Canberra) have been working on the geological sourcing of jade (nephrite) pieces found on Southeast Asian Iron Age sites and more especially the lingling'o and bicephalous ornaments (Hung et al. 2007). Their analysis of the material from KSK indicated that part of the assemblage seemed to originate from the East Taiwanese source of Fengtian; other nephrite and mica material are from as yet unknown sources. This research has revealed that the green nephrite from the Fengtian source was used to make two very specific forms of ear pendant distributed through the network 
that extended from the Philippines to peninsular Thailand via East Malaysia, South Vietnam and eastern Cambodia (Hung et al. 2007). The assemblage comprises four pieces made of mica and 23 of nephrite.

Techniques: It is not possible to determine the average for the diameter of the perforation hole. Finishing techniques are East Asian and involve sawing, a technique especially adapted to this kind of fibrous stone. In the absence of an ethnoarchaeological data base of manufacturing techniques, we cannot compare and interpret further the traces left on the surface of the nephrite materials from Khao Sam Kaeo.

Quality: The quality criteria (stone quality, symmetry, surface smoothness and lustre) are not significant due to the fibrous nature of the raw material and the fact that polishing does not result in smoothness and lustre as it does in the case of carnelian. In addition there are no ethnographically-based frames of reference to help evaluate the quality of production, and no finished artefacts. The material we have is semi-finished at best, without final polishing. Table 2 should therefore be viewed cautiously since only four specimens were taken into account to evaluate symmetry and surface and only one specimen for lustre. Other specimens correspond to raw material or production waste and could not be integrated in order to rank the quality.

Style: Excluding raw material and fragments, there is only a small range of shapes (Table 2): three, comprising the lingling' $\mathrm{O}$, the bicephalous ornament (Nguyen et al. 1995; Reinecke \& Luyen 2009) and bracelets, a range even narrower at Khao Sam Kaeo due the fact that the assemblage consists mainly of production waste and partially worked raw material. Given the small number of pieces, no average dimension can be provided.

Location: The location of this type of production is quite well delineated (Fig. 8). The manufacturing evidence comes both from unprovenanced (though I was shown where the looting pits were on top of Hill 3 ) and excavated contexts. A bicephalous ornament preform and an unfinished one, maybe a waster, were found on the top of Hill 3. W. Southworth reported another unfinished example found at Dai Lanh in Quang Nam Province, whilst a preparatory nephrite block had been unearthed at Giong Ca Vo (Southworth 2004, 212). Some specimens were unearthed from the same levels as where evidence of siliceous stone ornament production was found on the eastern plateau of Hill 3 , thus raising the question as to whether the same artisans might have been working both siliceous stone and jadeite.

The on-site distribution of this type of production is mainly found on Hills 3 and 4. The assemblage is too small for us to be able to assess significance with any confidence. Only the test against all artefacts was significant at $p=0.05$, but all scenarios showed more of this type in Valley 1 and/or Hill 3 than expected and less on Hill 1 (Fig. 7).

So far, it is impossible to determine whether these traditional East Asian technologies were practised by local, East Asian or South Asian craftsmen. One difficulty stems from the absence of proper technological study of nephrite technologies, a fact which greatly limits any attempt to evaluate the required skills, the ease and length of the transmission (apprenticeship) of this technology. A further difficulty stems from the fact that these artefacts are out of context, not discovered through controlled excavations at KSK.

\section{Group 3: The South Asian-related siliceous ornaments}

This type associates Indian raw material and highly skilled technologies with a style that includes religious or auspicious symbols. The assemblage comprises 151 beads, two earrings, one intaglio, four pendants (two fragments), nine rings, and 24 seals. Of these 170 artefacts, 17 show definite evidence of production and 14 possible evidence thereof.

Raw materials: This production involves traditional South Asian good-quality raw materials: carnelian, agate, jasper, rock crystal, amethyst and more rarely garnet. Agate and carnelian are the most abundant materials represented in this group; almost half of the artefacts are agate and about one third is carnelian (77 agate, 6 amethyst, 55 carnelian, 12 rock crystal, 5 garnet, 5 jasper, 1 mica, 1 nephrite, 5 stone). There is more variety in stone material used than there is in Group 1.

Techniques: The mean perforation hole diameter is $1.1 \mathrm{~mm}$ (range: 0.70 to $1.90 \mathrm{~mm}$ ). The rotary grinding stone predominates with significant use of leather bags for final polishing.

Quality: The overall quality is excellent. However, the lustre is medium (score 2).

Style: Whilst some morphology can be securely attributed to South Asia, such as South Asian-related auspicious and religious symbols, others are more ubiquitous. Some (not represented in Fig. 8) include ring and seals bearing or prepared for inscriptions (apparently exclusively in Brahmi). It is worth mentioning that most material belonging to this group lacks well-defined contexts; in fact they are often looted and interviews with villagers yielded, a posteriori, a fair number of these looted objects.

The material includes South Asian-related auspicious and religious symbols as exemplified by the 'mina-yugala' (double fish), swastika and a symbol 


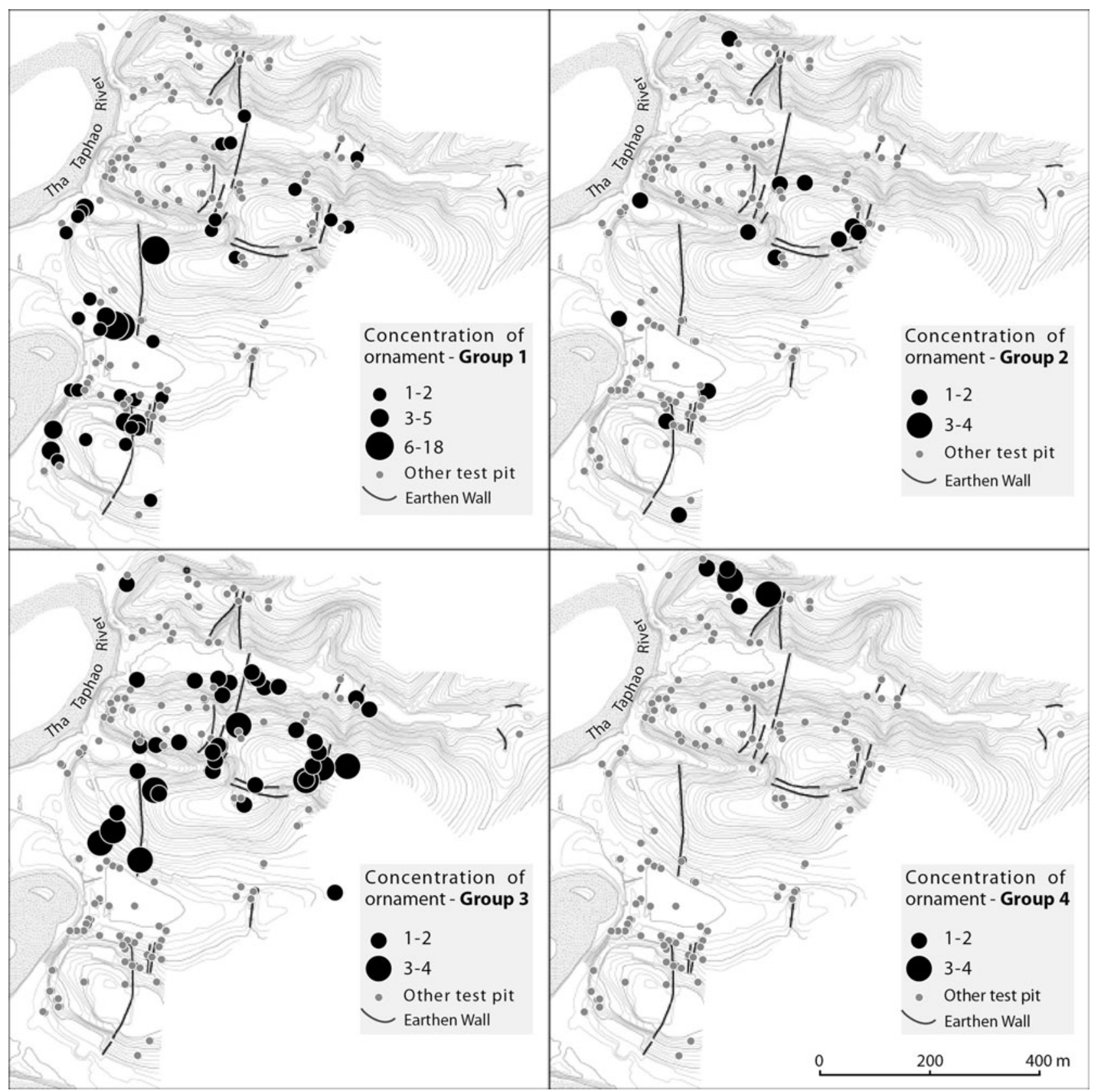

Figure 8. Distribution map of the four technological traditions of hard stone ornaments in Khao Sam Kaeo. (Drawing: J. Malakie.)

sometimes mislabelled 'triratna' or 'srivatsa' given that, as P. Skilling (pers. comm.) insists, these names and their meaning are later attributions. Some figurines, including animals such as lions or tigers, tortoises, frogs, fish, etc., cannot be related specifically to Indian imagery. Others, e.g. peacock, the 'hamsa' and the 'makara', more securely relate to Indian representations. The symbol which, for the sake of convenience, we refer to as 'triratna' is attested, a symbol which was adopted by the followers of the Buddha for veneration and worship at an unknown date. In later periods, for Buddhists, it represents the Triad of Buddhism: 'Buddha, Dharma and Sangha'.

Definite evidence for the manufacturing of this group has not been found. As this and the first type of production share the same raw materials and techniques (i.e. involving Indian skilled technologies) and the first stages of the production sequence (raw material, rough-outs and preforms), the only evidence distinguishing between them would correspond to 
unpolished or unperforated ornaments. However, the eastern plateau of Hill 3, where most of the specimens of this group come from, yielded evidence for the presence of workshops, most remains of which have quickly been looted. One of our test-pits included part of a workshop looted only a few days before our arrival (TP41).

Mean length is $11.27 \mathrm{~mm}$ (range: 2.68 to 36.78 $\mathrm{mm}$ ); mean diameter is $7.617 \mathrm{~mm}$ (range: 2.81 to $31.82 \mathrm{~mm}$ ) and mean thickness is $5.359 \mathrm{~mm}$ (range: 1.78 to $25.50 \mathrm{~mm}$ ). Group 3 is represented by small ornaments.

Location: The location for this type of production is well defined. Production evidence and the location of finished ornaments' are similar and cluster on Hill 2 , in the area that seems to coincide with the cemetery (the extent of which could not be determined due to the fact that it was impossible to excavate in this zone), and on Hill 3 (Fig. 7). The distribution was tested against that of all hard stone artefacts $(p=5.61)$, and the proxy measure for intensity of investigation $(p$ $=2.17$ ). The distribution across the site is significant at $p=0.05$, with fewer artefacts than expected located on Hill 1 and Valley 1 and more than expected in Valley 2 and on Hill 3 in all cases. Worthy of note is a concentration of figurines found higher in the cemetery area on the southwestern side of Hill 2.

\section{Group 4: A later Southeast Asian type of production}

The extensive and rapid looting that took place on Hill 4 in 2007 and the speed with which material was sent to feed collectors' networks did not give us much opportunity to observe many of the ornaments and much of the production evidence which had been reported to us. The very small amount of ornaments available makes it difficult to define with any certainty the type(s) available on this Hill. The material appears to be characterized by lower-quality mass-production techniques and mainly common morphologies. Production type 4 assemblage comprised three beads and five pendants, three of which show definite evidence of production

Raw materials: This type of production involves siliceous medium-quality stone (heterogeneous and opaque), almost exclusively agate but also some garnet.

Techniques: The perforation hole of the rare, perforated, specimens shown to us is large. The finishing techniques used can be qualified as mass-production techniques that do not require much skill, e.g. the leather bag finishing techniques mentioned above. Evidence of overheating problems is often encountered.
Quality: Based on the very restricted sample examined, the quality appears to be only mediocre (Table 2).

Style: The group comprises very few shapes and pendants (Fig. 10) and the limited amount of this type of production precludes any attempt to define it comprehensively. The style is difficult to define due to the limited amount of material available for study. It appears to include ubiquitous morphologies such as large spherical and ellipsoid beads as well as some flat agate pendants such as those found on prehistoric sites in central (Bellina 2007) and eastern Thailand such as in Noen U-Loke (Theunissen 2007). Notwithstanding the limited number of specimens taken into account, Figure 3 shows that Group 4 provides the largest ornaments produced on the site.

Location: Manufacturing evidence almost exclusively comes from looting in the northern zone of the plateau of Hill 4 in 2007 and 2008 and was collected on the surface or shown to us by villagers. It is difficult to determine its distribution due to its imprecise stylistic and technological definition. The graph in Figure 7 shows that more than expected specimens were observed in the very northern part of the site, on Hill 4 and Valley 4.

\section{Comparing and interpreting the four technological traditions}

In order to characterize the four technological groups, we shall first compare them. Then, comparison within a regional context will enable us to look at their modes of production and distribution.

\section{Comparison of the four technological traditions identified} at Khao Sam Kaeo

Among the four groups, Group 1 is characterized by the smallest average and maximum perforation diameter with a perforation hole of mean diameter of 1 $\mathrm{mm}$ (range: $0.60-1.50 \mathrm{~mm}$ ) (Fig. 11). This group also almost exclusively uses rotary grinders, corresponding to the most highly skilled and time-consuming polishing techniques observed.

In terms of quality, of the four groups, Group 1 scores highest in terms of every qualitative criterion. The morphometry of the beads of Group 1 can clearly be distinguished from those of other groups: they are smallest (Fig. 11). Their dimensions are of smallest average and maximum value (mean length: $9.194 \mathrm{~mm}$, ranging from 1.16 to $21.73 \mathrm{~mm}$; mean diameter: $6.68 \mathrm{~mm}$, ranging from 2.90 to $18.99 \mathrm{~m}$; and mean thickness: $3.40 \mathrm{~mm}$, ranging from 1.16 to $6.00 \mathrm{~mm}$ ). Morphologies are mainly dominated by double pyramid-based types. 


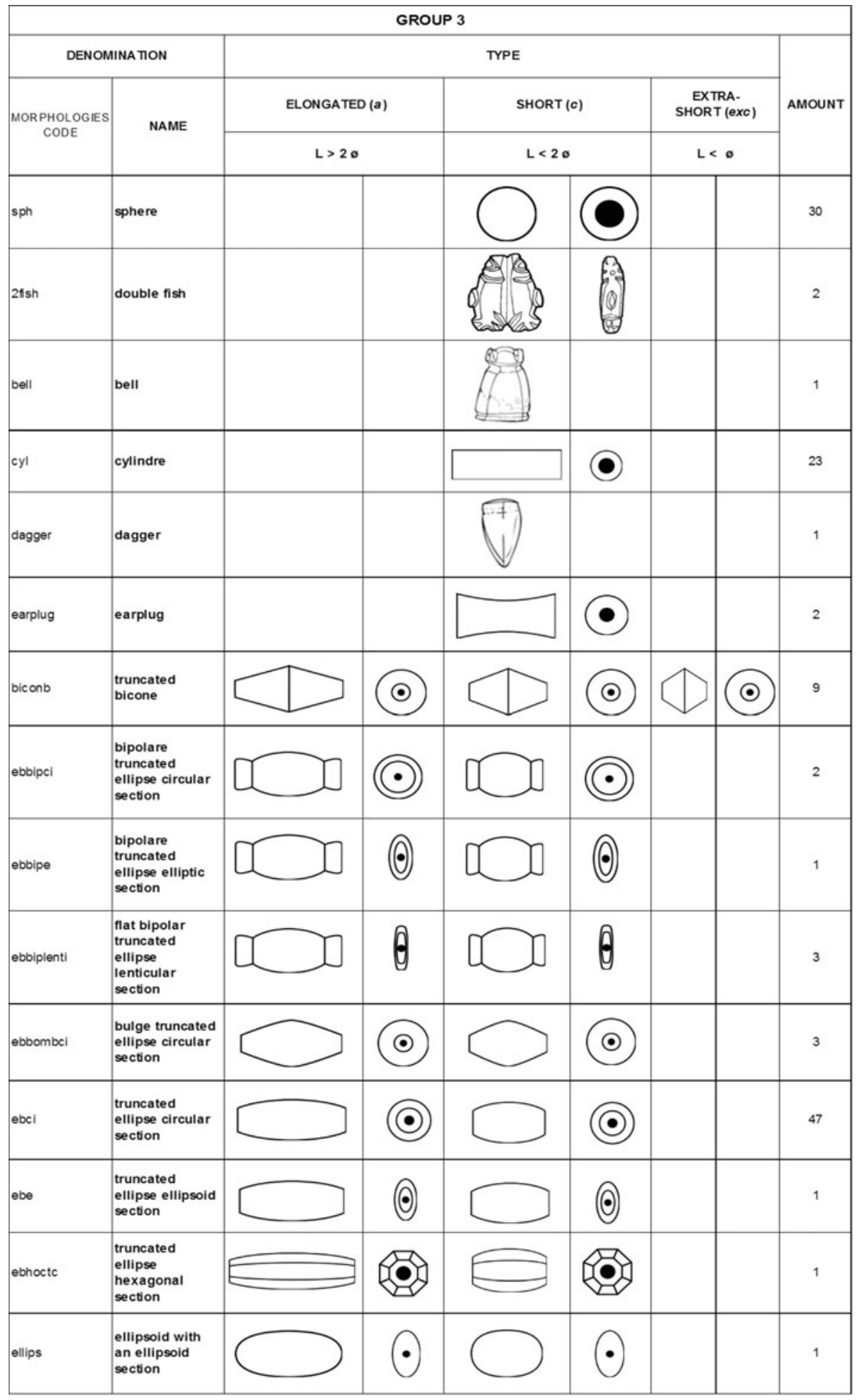

Figure 9. Continued. 
Bérénice Bellina

\begin{tabular}{|c|c|c|c|c|c|c|}
\hline $\operatorname{dog}$ & dog & & & as & & 1 \\
\hline ish & fish & & & & & 1 \\
\hline rower & nower & & & & & 1 \\
\hline horse & norse & & & & & 1 \\
\hline makara & makara & & & & & 2 \\
\hline monkey & monkey & & & & & 1 \\
\hline svastika & svastika & & & & & 1 \\
\hline tortolise & tortoise & & & & $\approx$ & 3 \\
\hline triratna & triratna & & & & ) & 4 \\
\hline |cosanedral & ICosanedral & & & & & 6 \\
\hline |intaglio & intaglio & & & & & 1 \\
\hline paralplat & paralplat & & & & 0 & 2 \\
\hline phexplat & phexplat & ए & 6 & & & 2 \\
\hline ppent & ppent & ए & $8 \sqrt{10}$ & & & 1 \\
\hline $\begin{array}{l}\text { pend.car3lob } \\
\text { plat }\end{array}$ & \begin{tabular}{|l} 
pend.car3lob \\
plat
\end{tabular} & & & & f & 1 \\
\hline pend.goutte & pend.goutte & & & & & 1 \\
\hline TOTAL & & & & & & 156 \\
\hline
\end{tabular}

Figure 9. Group 3 morphologies (seal, rings and fragments not included). (Drawing: B. Bellina and V. Bernard.) 


\begin{tabular}{|c|l|l|l|l|c|}
\hline \multicolumn{2}{|c|}{ GROUP 4 } \\
\hline $\begin{array}{c}\text { MORPHOLOGI } \\
\text { ES } \\
\text { CODE }\end{array}$
\end{tabular}

Figure 10. Group 4 morphologies.

Group 3, like Group 1, is characterized by skilled Indian techniques. However, in contrast to Group 1, the use of 'leather' bags is slightly more frequent. The perforation diameter in this group is also significantly larger than it is for Group 1 (Fig. 11). Although Group 3 is of a good quality, it is of slightly lower quality than Group 1 (Diagram 1). It is a result of highly skilled production, as for Group 1. Regarding the dimensions, the average and maximum values for all of these variables are consistently higher than those for Group 1 (Fig. 11). Group 3 is represented by small ornaments. However they are significantly larger than those of Group 1 but smaller than Group 4. There is greater variety in stone material used than there is in Group 1. It is this Group which displays the greatest morphological diversity, with 31 styles recorded in this study as opposed to just 16 for Group 1. The set includes several figurines and symbols pertaining to Indian representations.

As for the smaller Group 4, it is technologically characterized by polishing techniques that do not require any particular skill. The use of a grinder dominates and contrasts with Groups 1 and 3 in implementing mainly a rotary grinding stone. The perforation hole seen in these rare specimens is large. Based on the small number of artefacts, it appears that, in 

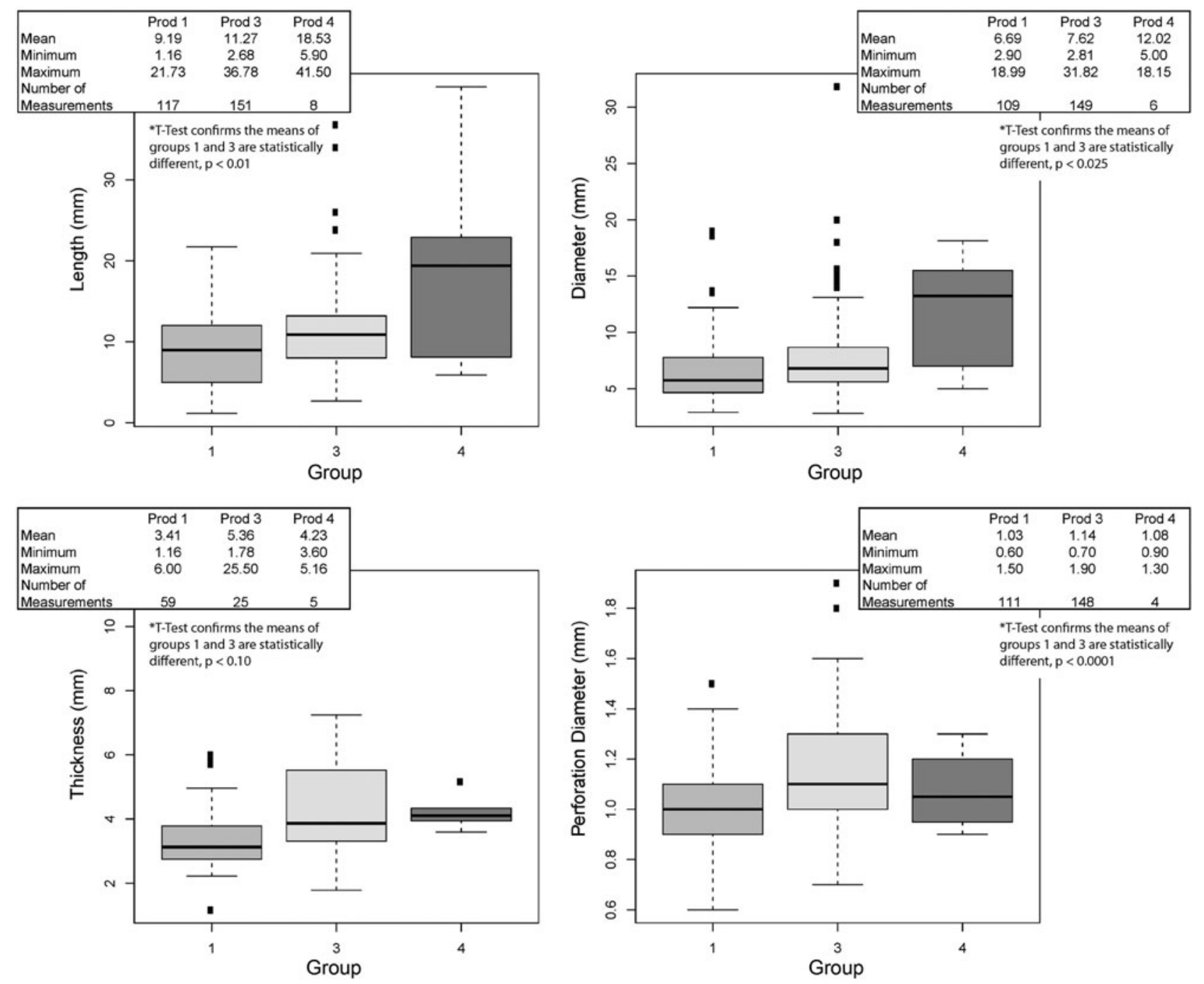

Figure 11. Whisker plot displaying the various dimensions and perforation holes of Groups 1, 3 and 4. Left box represents Group 1, the middle one Group 3, and the box on the right Group 4. (Drawing: J. Malakie.)

contrast to Groups 1 and 3, agate dominates with carnelian not being absent from this small sample. The group comprises only six types which are clearly distinct from those found in Groups 1 and 3.

The whisker plot (Fig. 11) illustrates that compared to Groups 3 and 4, Group 1 includes the smallest specimens in terms of length, diameter and thickness; the diameter of the perforation is also the smallest with an exceptionally small mean size of $1.03 \mathrm{~mm}$. Comparison of the four technological groups clearly shows how distinctive they are, suggesting different artisans and different destinations. What destination were these groups intended for? I shall try to answer this question by comparing these groups with other data.
Comparisons with other corpuses: interpreting the destination of the four technological groups

Group 1 is characterized by very skilfully made goodquality ornaments whose style is shared by maritime communities of the Late Prehistoric period in central and peninsular Thailand, at the Sa Huynh sites in coastal Vietnam and the Tabon Caves on Palawan Island. The flat lozenge-shaped beads (double bitroncated pyramid with a flat hexagonal section), or 2pyrbhexplat in my data base and more globally the double-pyramid family (which includes the flat lozenge bead) are abundant. The carnelian lingling'o from KSK compares well with that from Giong Ca Vo (Nguyen Kim Dung pers. comm. - 4 September 2006). The style probably entailed an artisan's efforts 

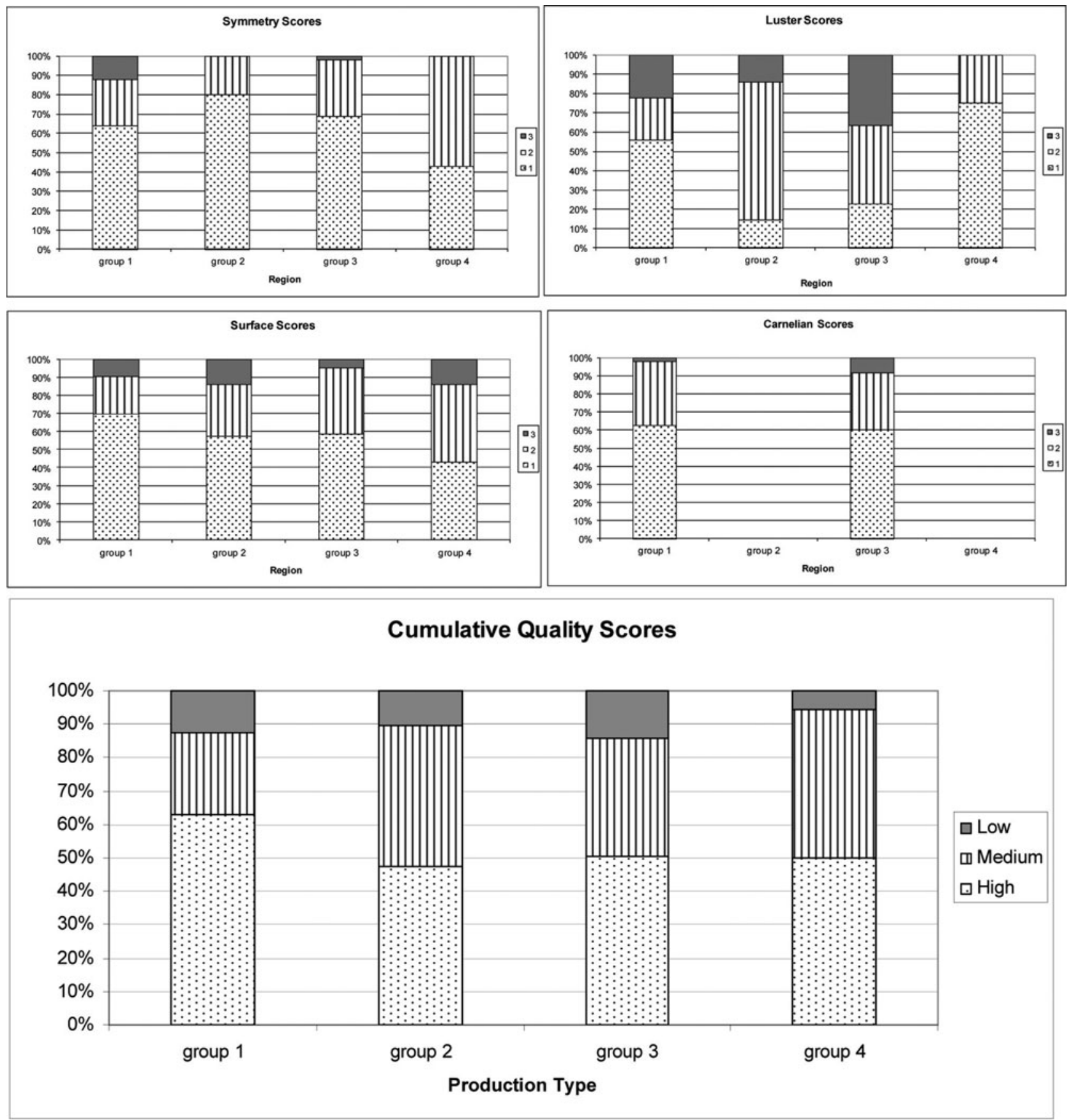

Diagram 1. Cumulative graphs comparing the scored qualitative criteria of the four groups.

to adapt technologies to very small and thin (often flat) beads, especially for perforation. The regional distribution of this group was already known and is further corroborated by other more recently analysed materials. For instance, at KSK, Group 1 was found to be associated with glass bracelet- and lapidary glass beadworking evidence which also involve Indian techniques (knapping and polishing). The glass used to make these bracelets and lapidary glass beads, very abundant at KSK and imported (Bellina et al. forthcoming), shows a similar regional distribution to that of Group 1: from the fourth century BC it is found in central Thailand, on Sa Huynh sites in south Vietnam and in the Tabon Caves on Palawan Island. Some gold ornaments, especially those with central knobs, show the same distribution pattern.

The southern part of the site also yielded a type of local ware, decorated with shell incisions, that shares 
similarities with the so-called 'Sa Huynh-Kalanay' complex (Bellina et al. forthcoming); the geographic extension of this complex partly overlaps that of the ornaments mentioned above (Bellina et al. forthcoming; Solheim 2006). I interpret this early local type of ceramic production (KSK-T1) and other sets of shared artefacts as elements of the South China Sea-oriented network culture. All assemblages found exclusively in the southern part of the site, whether ceramic, stone, glass or metal, correspond to rare products of advanced technology (Bellina et al. forthcoming).

These glass and stone ornament industries involving South Asian traditional complex knowledge and a South China Sea style represent our earliest evidence of the interconnecting relationship between the South China Sea network and Maritime Silk Roads (Bellina 2003; 2007). As early as the fourth to third centuries BC in Southeast Asia, ornaments were characterized by this distinct South China Sea network style associated with the most skilled and refined South Asian technologies. The discovery of production evidence for this hybrid at KSK suggests that South Asian craftpersons settled there, in a regional industrial centre that responded to specific socio-political regional requirements (Bellina 2001; 2003; 2007).

Like Group 1, Group 2 is characterized by a type of ornament shared by South China Sea maritime communities but perhaps extending further north. The regional distribution of this style partly overlaps Group 1 distribution but extends (or has been identified) further northeast to include areas stretching from Taiwan (Lan-yu Island southeast of Taiwan), the Philippines (Tabon Caves on Palawan Island), East Malaysia (Niah West Mouth, Sarawak), central and southern Vietnam, and eastern Cambodia, to central (in Ban Don Ta Phet and U Thong) and peninsular Thailand (KSK) (Hung et al. 2007; Solheim 1984). However it is plausible that the extension of Group 2 appears broader than that of Group 1 because of state-of-the-art bead studies: I have not yet studied any collection from Borneo or Taiwan.

Group 2 only includes a small range of shapes: three lingling'o comparable to those from Sa Huynh sites in Vietnam such as Giong Ca Vo and Lai Nghi and sites in the Philippines, the bicephalous ornament (Nguyen et al. 1995; Reinecke \& Luyen 2009) and bracelets (excluding fragments and raw material), a range reduced still further at KSK where most evidence consists only of production evidence and partially worked raw material (see Hung et al. 2007). However, though not recorded in this data base, this group should also include 'interrupted rings', some examples of which were recovered at KSK but could not be studied.
Specimens of this group are very rare in the southern part of the settlement and are mainly found along with production waste on Hills 3 and 4, associated with Group 3 specimens. The association of the production evidence for Group 2 and Group 3 suggests the possibility that both were made by the same artisans or that artisans from East and South Asia were working side by side. This area also yielded imported South Asian ceramics and, potentially, a small number of jars that seem to be associated with particular South China Sea groups identified at Hoa Diem and in the Philippines (Bouvet 2012). This production was made for groups belonging to the South China Sea cultural sphere, a group whose origin cannot be determined at this stage. Locally-produced nephrite ornaments also existed on the site, next to the Indian-related materials on Hills 3 and 4. Group 2 is attested slightly earlier than Group 3. Thus I would tend to interpret Group 2 as illustrating symbols of beliefs which survived in parallel to the Indian-related type (Group 3), whose symbols are in the process of being adopted.

Group 3, the Indian-inspired South China Sea type of production, associates Indian-inspired morphologies with highly skilled Indian technologies. The group comprises common morphologies alongside a wide variety of figurines, some clearly associated with Brahmanistic or Buddhist or Jain imagery.

In South Asia, many of the sites yield the 'triratna' amulets reported in major centres of Buddhism. The chronological range for this type of amulet seems to be confined to approximately the fifth to third centuries AD. The first-ever discovered 'triratna' amulets are made of carnelian and come from Bhir Mound, Taxila and were dated to the fifth to fourth centuries BC. Another symbol is the 'Mina Yugala' which is one of the 'astamangala' (a set of 11 to 13 auspicious symbols) whose antiquity, although still uncertain, is thought to be attributable to the Shunga period (third to second centuries $\mathrm{BC}$ ). This set of symbols has been used by followers of Jainism, Brahmanism and Buddhism. The 'Mina Yugala' appears as a decorative motif: garlands hanging on pegs and at the neck of Yaksi at Bharhut ('Batan Mara' pillar) from the third century BC (Cunningham 1879, pl. XXI); doors of the Buddhist monument of Sanci, stone architectural elements at Taxila (Marshall 1951, vol. III, pl. 140, no. 17) and on 'punch-marked coins' at Bhir Mound (Marshall 1951, vol. III, pl. 231, nos. 36, 38, 39, 48, 51). As an ornament, this symbol is not often reported in India. It first appeared in copper at Taxila during the Saka-Parthe period, i.e. the first century BC-AD (Marshall 1951, vol. III, 581, pl. 172h, no. 191).

In South Asia, as in Mahasthan (Bangladesh), these auspicious symbols frequently appear to be 
stamped onto the shoulders of early centuries AD ceramics and have been interpreted as being associated with Buddhist rituals (Gill et al. 2003). Other figurines found at KSK are also seldom found as amulets in India. This is the case of 'makara', a fantastical crocodilelike animal, the vehicle of 'Varuna', the river goddess Ganga or various 'Yaksa'. Often depicted on pottery, on decorative motifs in architecture they are only rarely reported as amulets and there are even fewer in hard stone: one of agate was discovered at Rajghat (Dikshit 1954) and another unstratified stone specimen at Kausambi. In the iconography, they appear from the second century BC at sites such as Hastinapura, Hastinapura and Kausambi (Jyotsna 2000).

The horse amulet is also very rare in South Asia where only two specimens in stone have been reported, one from Kausambi and the other from Indorkhera in Uttar Pradesh (Jyotsna 2000). Similarly, the monkey is an animal hardly ever represented in South Asia. To my knowledge, only one amulet has been recovered, from the Dharmarajika stupa in Taxila dated to about the first century BC (Beck 1941). A similar situation occurs for the well-known swastika symbol. Although frequently represented on bowls and on architectural decorative motifs, it is not often reported as amulets in South Asia and even less so in stone. Taxila, Bodhgaya, Maski, Rajghat and Kondapur have provided the very few known specimens which date from the Mauryan (fourth to second centuries BC) and Satavahana periods (third century BC to third century AD) (Jyotsna 2000).

Other images not recorded in the data base but seen at KSK (in private collections which we could look at but not analyse in detail) include the squirrel, for which no historical comparison was found in South Asia and the scorpion with a possible correlate in Taxilav (Marshall 1951) and possibly two at Kausambi (Jyotsna 2000).

Other amulets belonging to South Asian imagery such as the stupa were identified at KSK. Two were observed in the Suthi Rattana collection, one in rock crystal and the other in gold, but are not included in the data base. In South Asia, two reported specimens were found at Bhokardan, made out of ivory (first century $\mathrm{BC}$ to third century $\mathrm{AD}$ ) and of terracotta (third century AD) (Jyotsna 2000).

In summary, Group 3 is characterized by products of high technological quality and by a wide range of morphologies inspired by the South Asian imagery but developed to an extent not seen elsewhere in South Asia.

Group 3 is found amidst other Indian or Indianinspired materials: Indian imported Fine Wares which include 'rouletted ware' and 'knobbed ware' to men- tion just a few and locally made Indian-related ware (KSK-ECR 1, KSK-ECR 2, KSK-Black ware and the KSK-Black and Red ware) (Bouvet 2012). This Indianrelated material was found amidst what is currently the most important Western Han Chinese collection beyond north Vietnam, a well-dated set dating from the mid-third century вс at earliest (see Bellina et al. forthcoming; Peronnet \& Srikanlanya forthcoming). This part of the site also yielded technical ceramics associated with a South Asian-type of high-tin bronze production (Murillo-Barroso et al. 2010). It is possible that KSK imported the copper metal lacking in the Thai-Malay Peninsula and exploited the rich tin ores of the Peninsula in order to produce high-tin bronze ingots for bowl manufacture or exchange (MurilloBarroso et al. 2010; Pryce et al. 2008).

Given the expertise implemented in producing Group 3, I hypothesize that it was probably made by South Asian artisans or local artisans trained by South Asians. This group was also likely produced at a slightly later stage than Group 1. This assumption is based on evidence from, first the site's evolution through time (Bellina et al. forthcoming), second the associated materials, all of a slightly later period than Group 1, and third regional comparisons. In fact, the style of Group 3, including animals such as lions or tigers, tortoises, frogs, fish, etc. which are not specific to the Indian imagery suddenly appear and spread across South and Southeast Asia during the late centuries BC and early centuries AD. The Southeast Asian sites also display other Indian-related materials. The symbolic repertoire displayed by Group 3 is found on late prehistoric/protohistoric sites such as Tha Chana in Surat Thani province, Ban Kruay Nok and Phu Khao Thong in Ranong province (pers. observ.) and in the Mekong Delta region (Bellina 2007).

Group 3 was probably aimed at the South China Sea network adapting Indian-inspired imagery or cultural traits at Khao Sam Kaeo and in other Southeast Asian sites like in Ban Don Ta Phet in central Thailand. At KSK, several specimens have been unearthed from the cemetery area in the southwestern part of Hill 2, a cemetery that might have been mainly dedicated to local populations. This 'Indianized South China Sea repertoire' differs in many respects to what is found in contemporary South Asia. Indeed, as noted above, Group 3 associates a vast range of morphologies, some of them very rare or absent in South Asia itself, with production of a high quality which is also infrequent in South Asia. It is possible that the widely distributed high-tin bronze bowls also belonged to this Indian-inspired South China Sea repertoire. Such an explanation could account for the absence of exactly comparable material in South Asia. All of these 
later Indian-inspired productions, whose distribution quickly expanded within Southeast Asian sites of the late prehistoric/protohistoric period, would have mainly been aimed at the South China Sea network in the process of adapting Indian cultural features (Glover \& Bellina 2011).

Group 4 suffers from the small number of specimens and from a lack of secured context. It is difficult to say whether this type of production results from the transfer of Indian mass-production techniques or if it was inherited from a local tradition exemplified by polished axes occurring frequently in the region. The latter option sounds less plausible as the few beads which I have encountered in the region were made of soft stone or shell. Made on Hill 4 and found amongst Han material, this lower-quality type of production did not require great skill. It is also the latest group produced on the site since the Han material dates it at best from the late third century AD.

Some of the morphological types, especially the agate pendants, are commonly found on the slightly later late prehistoric sites of central (sites in Lopburi region) and eastern Thailand (Noen U-Loke) (Theunissen 2007) and in protohistoric sites in the Mekong delta region (Nen Chua) (Bellina 2007). No specimen of this group has been identified anywhere on the site other than on Hill 4. I suspect this type of production was probably for export for another later, as yet unidentified, late prehistoric Southeast Asian network.

\section{Discussion: production system socio-political environment and identities}

After discussing characteristics of the production system, I will draw on the sparse historical and ethnographic accounts available concerning craftsmanship in order to infer the nature of the interplay between socio-political context and this industry and the role which production systems may have played in the construction of cultural identities.

The production system at KSK is at the small household scale, as suggested by the relatively 'low' concentration of production evidence found within diminuitive domestic structures (Bellina in press; Bellina-Pryce \& Silapanth 2008). Such reconstruction coincides well with historical sources that tell us that this scale was the norm throughout Southeast Asia (Reid 1988).

It is also characterized by its diversity and hybrid configurations. This diversity can be verified within and between workshops, and applies to the types produced and the technologies implemented. As an illustration, several stages of the chaine opératoire were common in the making of Group 1 stone ornaments as well as lapidary glass beads in workshops at the bottom of Hill 2. As far as I am aware, in South Asia, guilds working hard stone are socially and geographically distinct from those working glass. However, because both are siliceous material, mechanical properties of glass and chalcedony (conchoidal fracture) are the same. Within the framework of an experiment carried out by Brill and Roux (Bril et al. 2005), artisans from Khambat workshops were asked to knap blocks of glass rather than their familiar chalcedony into unusual shapes. The aim of this experiment was to test whether the ability of the experts to transfer their knapping knowledge could indicate their level of dexterity. The investigation concluded that in order to be successful, such transfer required a high degree of expertise in the 'technique' if artisans were to adapt it. ${ }^{5}$ Even if not commonly practised, this adaptation appears possible and only emphasizes even more the degree of expertise of the South Asian artisans present at KSK when constrained by 'atypical' demands. Diversity is also expressed by the range of raw material and associated technological traditions. As an illustration, siliceous hard stone and jadeite ornaments seem to have been worked within the same production zone on Hill 3, and very likely within the same workshop (as in TP41, partly disturbed by looting activities). The diversity of production systems and the variety of the manufactured products paints a picture of the extensive and complex social network that intersects at KSK but also its evolution through time.

The hybrid configuration of this production system is interpreted as reflecting artisan adaptation to specific demands. What could be the politico-economic environment for the fruition/ development/rise of such industry? Can such a hybrid industry be created purely by the agency of the consumers in a free 'market' system with independent specialists moving freely and being 'rational actors exploiting economic opportunity as in the case of the East African Swahili context' (Wynne-Jones \& Mapunda 2008, 14)? Or should it be seen as the produce of an elite-attached production?

Brumfield and Earle (1987) remind us that concentration of independent specialists at large regional centres does not always relate to political factors (such as urbanization) or elite strategies but to opportunities which these large regional centres offered by concentrating networks. Independent specialists would move freely from one centre to another according to demand (Brumfield \& Earle 1987). An ethnoarchaeological study led by Wynne-Jones and Mapunda (2008) has shown the existence of free artisans of different ethnic origin migrating to the producing 
region on Mafia Island in order to manufacture pots for trans-ethnic networks of communities structured by enduring social practices in the Swahili cosmopolitan context. In this latter case, artisans consciously produce material culture purchased by a network of communities sharing social practices. However, these artisans' political environment may have been quite different from KSK. Historical sources tell us that in the Southeast Asian context, independent craft specialists seem only to be reported in former capitals where the ruler's power had declined or had disappeared; in such cases artisans were moving from one centre to another (Reid 1988, 101).

Should we instead consider attached specialists at Khao Sam Kaeo? Brumfield and Earle (1987) explain that attached specialization involves the manufacture of restricted goods mostly aimed at elite patron consumption and redistribution through gifts; craftsmen subsistence is supported partially or wholly by the sponsor. They argue that this kind of specialization develops in complex societies and results from the elite's desire to control both the production and distribution of political currency used for legitimization, allianceconstruction strategies and stabilization of authority. Because of the elite control and the dependence of the attached specialists, their workshops were expected to be found in the vicinity of the elite habitation such as in a major regional centre.

Extrapolating from later sources, KSK industries with restricted ornaments made to order seem to better match this second description. Indeed, the site shows a complex spatial configuration with its socio-professional compartmentalization emphasized by walls (Malakie LaClair \& Bevan forthcoming). So far, no production has been recovered outside those boundaries, the function of which is interpreted to have been symbolic as well as practical (soil retention in a monsoon climate) (Bellina in press). Craft specialists are not dispersed in the region but are concentrated within well-delineated parts of the settlement. Historical accounts show that large cities of the fifteenth and seventeenth centuries AD displayed socioprofessional quarters, each dedicated to a specific specialization. This concentration can be explained by the high demand in a big urban centre context, on the one hand because they were nodes concentrating both local and international trading routes and on the other because the wealthiest consumers, the royal courts and the merchants, were there. Urban production centres continued to display this organization into the nineteenth century in some places, such as at Surabaya, where artisans as well as communities of foreign traders continued to live in their specialist quarters or 'kampung' (hence 'compound') (Reid
1988, 101-3). Except perhaps in the case of Group 4, whose destination could not be determined, ornaments seem to satisfy specific well-defined demands for very fine-quality materials and highly skilled craftsmanship whose style is specific to a South China Sea network. Was this demand exclusively for 'royal' courts and merchant-aristocrats and, if so, were they exerting some sort of control? It is difficult to answer this question with the data available.

Firstly, the socio-political structure of early polities in the Southeast Asia during the late prehistoric period is not yet very well defined but is often hypothesized to be of competing chiefdoms (Higham 2002, 168-298; Higham \& Thosarat 2004; Kim et al. 2010). At KSK, mortuary and settlement hierarchy evidence for social stratification and political centralization does not exist. This is due to the dearth of archaeological investigation in the region, as well as the near complete destruction of the site due to looting activities leaving only very few places for excavation. Secondly, the socio-political environment of craft systems and their evolution in relation to trade ${ }^{6}$ are under-investigated topics in archaeological research in Southeast Asia, the only exception being the systematic study carried out concerning the historic chiefdoms of the Philippines by L.L. Junker (1999). Even for major historical maritime-trading polities such as Srivijaya, Champa or Malacca, archaeological data are lacking. Allusions to the socio-economic and political context of craft specialists can be found in much later textual sources or in even more recent ethnographic descriptions. The latter mostly relates to attached specialists. Ethnohistorical sources and archaeological research on the political economy of Philippines chiefdoms show that 'political currency' was generated through alliance-structured as well as sponsorship of luxury good artisans (Junker 1999).

Historical accounts relate how, in the case of other high-value industries (silversmith and goldsmith), shops were not stocked with ready-made wares. William Dampier (1651-1715), observed that the reason artisans' reluctance to accumulate a large stock was explained by the dual risks of burglary and using expensive raw materials without a secure commission (Reid 1988, 101-3). It is likely that this situation applies to other precious materials such as exotic hard stone ornaments. At KSK, no stock (of finished products) was recovered or reported in or near the workshops, or anywhere on the site. Finished products were found isolated, not as a group.

How to interpret this commissioned work in socio-political terms? Several European accounts have described the system of temporary patronage. They emphasized the security which the commissioned 
work created with the buyer. Some of the observers also found the status of artisans comparable to that of slaves or bondsmen. Reid underlines the haziness of the distinction between the status of bought slaves and commissioned craftsmen (Reid 1988, 102). In royal capitals the court and the wealthy merchantaristocrats provided much of the demand for the products made there. Artisans were treated with consideration by their patrons but their work was considered as a tribute to the king or to merchant official. Finally, artisans were maintained with patronage rather than being paid for specific works. The Frenchman P. Poivre at the Court of Siam describes the 'corvée' system that dominated artisans: they had to work for free all their life in the service of the prince (Reid 1988, 103).

Labour control is a core component of sociopolitical practice and characterizes many Southeast Asian societies based on a patriarchal system. Prestige was based on a capacity to control labour, whether for mundane tasks such as edifice construction, warfare and, I argue, perhaps, for the production of social markers by craft specialists. The vertical obligation, with the personal binds of loyalty between leader and a network of clients, provided security and protection in an otherwise turbulent political and natural environment. In this social system, the leader imposed himself on others by means of his charisma and ability to weave a network of clients. This pyramid of supporters includes populations of various socio-political organizations and environments. They comprise socially complex cosmopolitan populations from the coast and of socially less complex populations further upstream, the 'Orang-Asli' providing forest and mineral resources needed to make ports appealing for merchants. This network also comprised other socially less complex populations, such as the sea-nomads or 'Orang Laut', who never ceased to interact closely with coastal polities, even forging kinship links through marriage and adoption (Andaya 2008). Leaders of coastal-trading polities entertained valuable but volatile relationships with 'Orang Laut', crucial to the success of any entrepôt. Subjects and allies of the rulers of those trading-polities, they maintained security in the sea lanes and guided foreign merchants to frequent their ruler's port. Their reputation as pirates owes much to their control of the sea including through harassment and destruction of their ruler's competitors. This standing also comes from raids on passing shipping and coastal settlements for merchandise, including slaves. These activities were often commanded by the coastal-polity lord. Finally, they also gathered marine products like seaweed and mother-of-pearl for the Chinese market (Andaya 2008).
Leaders of trading polities also competed as peers. They thus had to weave their network of volatile allies and dependents in order to build their power and prestige as well as to ensure the wealth of their trading polity. They attributed prestige goods, such as ornaments and bestowed honorific titles to garner support from some of the volatile allies that could not be constrained by coercion. In this scenario, artisans were producing the political currency to build this pyramidal network.

However, artisans may have played another crucial role in the frame of this peer-polity interaction between the late prehistoric polities. In the fifteenthsixteenth century, the increasing inter-polity competition to control foreign prestige-goods trade between Philippine chiefdoms resulted in intensification of prestige-goods exchange, of inter-polity raiding and warfare, and of the organization of more sophisticated 'feasts of merit' (Junker 1999, 18). Prowess might have been increased by mobilizing labour but also in controlling special skilled labour in the realm of arts, techniques or knowledge (religious, magical, etc). Controlling highly skilled production systems with associated artisans, whether foreign or not but with different technological abilities, probably participated in the prestige apparatus of the elite. In the few references of which I am aware, the associated specialists appear to have contributed to the prestige of the leaders in historical sultanates. Beaulieu reports that at Aceh, the Sultan Iskandar Muda was said to have 300 artisans in his service and that he managed to lure another French one away from Admiral Beaulieu (Beaulieu $1666,90,100)$.

Finally, it is possible that artisans also produced a means of internal stabilization. According to chronicles and ethnographic accounts, the social structure within the cosmopolitan trading port-city proved difficult to maintain due to extremely challenging internal competition. In modern Malay city-states called 'negeri', A. Reid tells us that it 'was held together less by states than by elaborate kin and patronage networks. The Malay negeri ... were essentially built by merchants and their monarchs ruled either in conciliar fashion which incorporated a diversity of interests, or they ruled rather briefly.' He goes on to add that 'Foreign reports on Melaka show the ruler presiding over a range of powerful merchant-aristocrats of foreign origin, many controlling thousands of "slaves" or retainers. Pasai, the oldest of the Malayo-Muslim city-states, appears to have become notorious for the frequency with which its kings were discarded' (Reid 2000, 422).

To sum up, it is argued here that the production system probably contributed to the political 
legitimization of the trading elite, whether a ruler or a leading class. At KSK and also most likely other portcities yet to be excavated, industrial systems probably participated in stabilizing the political position in relation to three different types of rivalry.

The first was probably internal and generated by the diverse communities or clans of local and foreign traders, specialists or religious men staying more or less temporarily in port-cities. These groups were probably well aware of the novelties available in other port-cities and may have put more pressure on the port-city elite to remain up-to-date.

The second resulted from the need to maintain good relationships with other more volatile societies of different socio-political organization, be they sea populations or raw material collectors from the forested interior linked to the port-city; populations with whom they developed inter-dependant relationships. They had to stay in the pyramidal social construction as they were vital for the attractiveness of the trading polity and thus the power of its leader.

The third challenge was probably exerted by other societies of similar rank such as in other coastal trading polities with whom they were competing. This third one is, I believe, some sort of 'joust of prestige' between competing elites that took place in the context of competing trading polities. To what extent did those competitions encourage excellence by pushing the limits of expertise (technologies)? This rivalry through possible prestige contest-like interactions might also have contributed to dissemination of technologies, complex knowledge and beyond, advances amidst coastal urban elites. Such process could have played a significant role in the transfer of exogenous cultural traits.

An important result of the investigation of KSK is that it has revealed a sequence of cultural exchanges between distant populations. If technological Group 1 displayed the most sophisticated Indian technologies (applied to regional style), Group 3 attests to the transmission of South Asian ideational traits amongst local and regional populations. I cannot think of any other reason for these symbols to be produced in Southeast Asia if not for local and/or regional consumption. Of course some of these ornaments could have been acquired by South Asian merchants, artisans or other religious persons staying temporarily in Southeast Asia; however it would have been easier for them to bring the objects directly from South Asia. Besides, as explained before, I do not consider this style to be 'Indian'. This regional style was not merely copied or imported from South Asia but exaggerated several of its traits. Groups 1 and 3 not only implemented highly skilled techniques, sometimes pushing them to their technical limits (especially the minute perforations), but they also amplified Indian imagery. Unless this situation results from archaeological bias and does not reflect reality, I am unaware of any assemblages in India showing such a concentration of a large range of symbols or even the development of new types. As an illustration, I have never come across pendants whose multiple facets display different auspicious symbols or etched beads bearing a multitude of minute swastikas such as those from KSK. There, the repertoire of figurines seems to be more diversified, with a wide range of animal (real or fantastical) and types unknown in India. These later 'South China Sea Indianized' products, motifs and techniques, the distribution of which quickly expanded within the Southeast Asian sites of the late prehistoric period, would have been produced mainly for Southeast Asian populations either in the process of 'Indianization', probably the coastal trading elites or those wanting the same symbolic items as those acquired by the former, at KSK and/or elsewhere as for instance at the contemporary site of Ban Don Ta Phet (Glover \& Bellina 2011). What shows through here is that, at this period and with the groups concerned here (competing elites from early trading polities), this transformation took the shape of over-emphasizing the attributes of otherness, attributes of what were deemed to be sophisticated and modern. Paralleling Greek models exaggerated in the Roman world, the 'more Indian than Indian' cultural trait produced goes with excellence. The social identity built by the South China Sea populations rests on the sublimation of what are no longer South Asian cultural traits. Such characteristics in the cultural exchange process have also been attested in later historical periods in the realm of Khmer architecture (Dagens 2005; 2009), and in urbanism at Oc eo (Bourdonneau 2010) and may thus represent a recurrent behaviour.

\section{Conclusion}

In accordance with some historians' positions, this study of early trade-oriented industries suggests a continuity of socio-political practices. The evolution of these industries and the strategies they may have served show how the 'otherness' was handled in the construction of social identity. A core characteristic of this South China Sea network culture was its capacity to adopt and exaggerate any foreign innovations that were deemed useful for socio-political strategies.

The nature of interactions between lowland maritime-oriented polities and inland populations and strategies at play are questions that are now being tackled by the current focus of the Franco-Thai archaeological mission. What types of ornaments were 
distributed amongst the upland populations? Did they acquire specific types of production with a specific style and quality that were made for them, thus impacting production in coastal port-cities? Or, on the other hand, were elites from the interior seeking to obtain types similar to those acquired by the coastal elite, an imitation that would have led to uniformity in taste and production? Given that being located on the possible transpeninsular routes made possible the circulation of goods and people from one maritime basin to another, would ornaments inform us about these populations' reactions to their involvement in longdistance exchange? Being in contact with foreigners passing through or possibly sojourning for some time on the Peninsula, did these populations experience and maybe also contribute to cultural change? It is high time those populations, marginalized from broad historical reconstructions, are integrated and evaluated not only for how they were impacted but also how they may themselves have impacted others. These studies of industries should eventually allow us to address how a much earlier 'globalization' may have contributed significantly to the creation of cultural identities in Southeast Asia.

\section{Acknowledgements}

The author wishes to acknowledge Valentine Roux, Oliver Pryce and Roger Blench for their comments on an earlier version of this article. The Franco-Thai archaeological Mission in the upper Thai-Malay peninsula was created in 2005. Its directors are B. Bellina (CNRS) and P. Silapanth (Silpakorn University, Bangkok) and from 2012 C. Thongcharoenchaikit (National Science Museum). I express my deep gratitude to the Commission des Fouilles of the French Ministry of Foreign Affairs, to the CNRS and in particular its Direction des Relations Européennes et Internationales who have funded this research project. I also acknowledge the support of the Ecole française d'Extrême-Orient, the French Embassy in Thailand, the UMR CNRS 7528 'Mondes iranien et indien', the UMR CNRS 7055 'Préhistoire et Technologie', the National Research Council of Thailand and the Fine Arts Department, Dr Bunchar of the Suthi Rattana foundation. I wish to thank Praon Silapanth and each member of the team and contributors: J. Allen, V. Bernard, P. Bouvet, L. Biggs, C. Castillo, A. Favereau, J. Malakie, M. Murcillo-Barosso, T.O. Pryce, S. Peronnet, L. Dussubieux, Hsiao-chun Hung and Yoshiyuki Iizuka, Nattha Chuenwattana and Jean-Pierre Gaston-Aubert. Finally, a special acknowledgement to Julie Malakie Laclair who has conducted the GIS study of artefacts in Khao Sam Khao and produced the distribution maps displayed in this article.

\section{Notes}

1. I follow Bentley's minimal characterizing criterion which is that integration takes place when cross- cultural interactions 'bring about a division of labour between and among interacting societies or when they facilitate commercial, biological, or cultural exchanges between and among these socially and economically integrated maritime spaces interacting societies on a regular and systematic basis' (Bentley 1999, 218).

2. Traditionally, three stages for globalization are considered. The first took place at the end of the Middle Ages and at the beginning of the Renaissance, and corresponds to the emergence of capitalist world-economies (see Braudel 1966), with big discoveries and the constitution of networks of trade cities. The second globalization takes place during the industrial revolutions of the nineteenth century, when states create industrial societies and exchanges intensify. The third begins in the 1980s.

3. The study is based on a frame of reference elaborated after an ethnoarchaeological study carried out in the Cambay workshops (Roux 2000) which made possible the analysis of manufacturing techniques. This study allowed the characterization of every stage of the chaine operatoire, from the extraction, heating and knapping (Pelegrin 2000) to the operation of final polishing (d'Errico et al. 2000). The current work follows in-depth doctoral research carried out on late prehistoric and early historic hard stone industries in South and Southeast Asia (Bellina 2003; 2007).

4. The different tools and ethnographic cases showing the different combinations and results obtained are described in detail in Roux (2000).

5. The expert 'knows better what to look for and how to turn the information perceived into action and movement: this capacity is directly associated to a high degree of control of the technique'. A highly skilled expert will be able to constrain mutuality relations between himself and his environment (i.e. the stone at different points in the knapping process) in such a way as to perceive the affordances (Gibson 1977; 1986; Stoffregen 2000), that is the properties of the system (stone/hammer/organism) that lead to the characteristics of the next flake, and consequently the next strike. In other words, the high-level expert knows better what to look for and how to turn the information perceived into action and movement: this capacity is directly associated to a high degree of control of the technique (Bril et al. 2005, 70).

6. Khuan Lukpad or Khlong Thom has been excavated on several occasions but never extensively, a situation that may be had to do with the discouraging and desolating spectacle which a heavily looted site has to offer (Bronson 1990; Veraprasert 1992).

Bérénice Bellina CNRS-Mondes iranien et indien 27 rue Paul Bert Ivry-sur-Seine 94204 France Email: berenice.bellina@cnrs.fr 


\section{References}

Amselle, J.-L., 2000. La globalisation Grand partage ou mauvais cadrage ? L'Homme 156, 207-26.

Andaya, L.Y., 2008. Leaves of the Same Tree: Trade and Ethnicity in the Straits of Melaka. Honolulu (HI): University of Hawaii Press.

Appadurai, A. (ed.), 1986. The Social Life of Things. Cambridge: Cambridge University Press.

Assayag, J., 1998. La culture comme fait social global? Anthropologie et (post)modernité. L'Homme 38(148), 201-23.

Bacus, E.A., 2003. Style of alliance?: decorated earthenwares in late prehistoric and protohistoric Philippine polities, in Earthenwares in Southeast Asia, ed. J. Miksic. Singapore: Singapore University Press, 39-51.

Beaujard, P., 2005. The Indian Ocean in Eurasian and African world-systems before the sixteenth century. Journal of World History 16(4), 411-65.

Beaujard, P., 2012a. Les mondes de l'océan Indien: de la formation de l'etat au premier système-monde afro-eurasien, tome 1. Paris: Armand Colin.

Beaujard, P., 2012b. Les mondes de l'océan Indie: l'océan Indien, au cour des globalisations de l'Ancien Monde (7e-15e siècles), tome 2. Paris, Armand Colin.

Beaujard, P., L. Berger \& P. Norel (eds.), 2009. Histoire globale, mondialisations et capitalisme. Paris: La Découverte.

Beaulieu, A. de, 1666. Mémoires de voyageaux Indes orientales du Général de Beaulieu, dressés par luy-mesme, in Relations de Divers Voyages Curieux, vol. II, ed. M. Thévenot. Paris: Cramoisy, 144.

Beck, H.C., 1941. The Beads from Taxila. (Memoir of the Archaeological Survey of India 65.) New Delhi: Archaeological Survey of India.

Bellina, B., 2001. Témoinages archéologiques déchanges entre l'Inde et l'Asie du Sud-Est: morphologie, morphométrie et techniques de fabrication des perles en agate et en cornaline. Unpublished PhD dissertation, Université Paris III, Paris.

Bellina, B., 2003. Beads, social change and interaction between India and Southeast Asia. Antiquity 77(296), 285-97.

Bellina, B., 2007. Cultural Exchange Between India and Southeast Asia: Production and Distribution of Hard Stone Ornaments, c. VI bc-c. ad VI. Paris: Éditions de la Maison des sciences de l'Homme.

Bellina, B., 2009. Late prehistoric South China Sea coastal people: Peninsular Thailand and Sa Huynh communities (draft), in International Conference on 100 Years Discovery and Research of Sa Huynh Culture, co-organized by Vietnam Institute of Culture and Arts Studies (Ministry of Culture, Sports and Tourism) and Department of Culture, Sport and Tourism of Quang Ngai province (Peoples Committee of Quang Ngai province), held from July 22, 2009 to July 24, 2009. Petrosetco Tower Hotel, Quang Ngai city, Quang Ngai, Vietnam. Unpublished manuscript.
Bellina, B., 2011. Echanges préhistoriques et hybridations culturelles entre l'Est de l'Océan indien et la Mer de Chine. http://www.reseau-asie.com/ colloque/4eme-congres-2011/ et Actes du Congrès Réseau Asie \& Pacifique 2011

Bellina, B., in press. The inception of the trans-national processes between the Indian Ocean and the South China Sea from an early city-state on the Thai-Malay Peninsula (4th-2nd C. BCE), Proceedings of the International Conference, in The Ports of the Indian Ocean, from the Red Sea to the Gulf of Bengal, eds. M.-F. Boussac, S. Roychoudhury, J.-F. Salles \& J.-B. Yon. Delhi: Primus Books.

Bellina, B., G. Epinal \& A. Favereau 2012. Caractérisation préliminaire des poteries marqueurs déchanges en Mer de Chine Méridionale à la fin de la préhistoire. Archipel 84, 7-33.

Bellina, B., P. Silapanth \& B. Chaisuwan, forthcoming. The development of coastal polities in the Upper ThaiMalay Peninsula in the late first millennium BCE and the inception of long lasting economic and cultural exchange between polities on the east side of the Indian Ocean and the South China Sea, in Before Siam was Born: New Insights on the Art and Archaeology of Pre-modern Thailand and its Neighbouring Regions, eds. N. Revire \& S. Murphy. Bangkok: River Books.

Bellina-Pryce, B., 2008. Dossier - The archaeology of transAsiatic exchange: technological and settlement evidence from Khao Sam Kaeo, Peninsula Thailand. Bulletin de l'École française d'Extrême-Orient 93, 249390.

Bellina-Pryce, B. \& P. Silapanth, 2008. Weaving cultural identities on trans-Asiatic networks: Upper Thai-Malay peninsula - an early socio-political landscape. Bulletin de l'Ecole Française d'Extrême-Orient 93, 257-93.

Bellwood, P., 2011. Holocene population history in the Pacific region as a model for worldwide food producer dispersals. Current Anthropology 52 (Suppl. 4), S36378.

Benda, H.J., 1962. The structure of Southeast Asian History. Journal of Southeast Asian History 3(1), 103-38.

Bennett, A., 2008. Bronze casting technology in protohistoric Southeast Asia, the technology and its origins, in Archaeology in Southeast Asia: From Homo erectus to the Living Traditions, Choice of Papers from the 11th EurASEAA Conference, Bougon 2006, eds. J.-P. Pautreau, A. Coupey, V. Zeitoun \& E. Rambault. Chiang-Mai: European Association of Southeast Asian Archaeologists, 151-64.

Bennett, A. \& I.C. Glover, 1992. Decorated high-tin bronzes from Thailand's prehistory, in Southeast Asian Archaeology 1990, ed. I. Glover. (Centre for Southeast Asian Studies.) Hull: Hull University, 187-208.

Bentley, J. H., 1999. Sea and Ocean Basins as Frameworks of Historical Analysis. Geographical Review 89(2), 215-24.

Bertrand, R., 2007. Rencontres impériales: l'histoire connectée et les relations euro-asiatiques. Revue dHistoire Moderne et Contemporaine 54(5), 69-89. 
Bourdonneau, E., 2010. Réhabiliter le Funan. Oc Eo ou la première Angkor. Bulletin de l'Ecole française d'Extrême-Orient 94(2007), 111-58.

Bouvet, P., 2012. Preliminary study of Indian and Indian style wares from Khao Sam Kaeo (Chumphon, Peninsular Thailand): fourth-second centuries BCE, in Early Interactions between South and Southeast Asia: Reflections on Cross-cultural Exchange, eds. P.-Y. Manguin, A. Mani \& G. Wade. Singapore: Institute of Southeast Asian Studies, Manohar, 287-301.

Braudel, F., 1966. La Méditerranée et le monde méditerranéen à l'époque de Philippe II, Armand Colin, Paris, 1949 (2e ed., 2 vol.)

Bril, B., V. Roux \& G. Dietrich et al. (eds.), 2005. Stone knapping: Khambhat (India), a unique opportunity, in Stone Knapping: the Necessary Conditions for a Uniquely Hominin Behaviour, eds. V. Roux \& B. Bril. (McDonald Institute Monographs.) Cambridge: McDonald Institute for Archaeological Research, 53-72.

Bromberger, C. \& D. Chelvallier, 1998. Carrières d'objets, in Carrières d'objets, eds. C. Bromberger \& D. Chelvallier. Paris: Editions de la Maison des sciences de l'homme, 1-16.

Bronson, B., 1977. Exchange at the upstream and downstream ends: notes towards a functional model of the coastal state in Southeast Asia, in Economic Exchange and Social Interaction in Southeast Asia: Perspectives from Prehistory, History and Ethnography, ed. K.E. Hutterer. (Michigan Papers on South and Southeast Asia No. 13, Center for South and Southeast Asian Studies.) Ann Arbor (MI): University of Michigan, 3952.

Bronson, B., 1990. Glass and beads at Khuan Lukpad, southern Thailand, in Southeast Asian Archaeology 1986, eds. I.C. Glover \& E. Glover. (British Archaeological Reports S-561.) Oxford: Archaeopress, 213-29.

Brumfield, E. \& T. Earle, 1987. Specialization, exchange, and complex societies: an introduction, in Specialization, Exchange, and Complex Societies, eds. E.B. Earle \& T.K. Earle. Cambridge: Cambridge University Press, $1-9$.

Bulbeck, D., 2008. An integrated perspective on the Austronesian diaspora: the switch from cereal agriculture to maritime foraging in the colonisation of Island Southeast Asia. Australian Archaeology 67, 31-51.

Cœdès, G., 1968. The Indianised States of Southeast Asia. Canberra: ANU Press.

Costin, C.L., 2001. Craft production systems, in Archaeology at the Millennium: a Sourcebook, eds. G.M. Feinman \& T.D. Price. New York (NY): Kluwer Academic/Plenum Publishers, 273-327.

Cunningham, A., 1879. The Stupa at Bhahrut. London: W.H. Allen and Co.

Dagens, B., 2005. Traités, temples et images du monde indienétudes d'histoire et d'archéologie. Paris: Presses Sorbonne Nouvelle.

Dagens, B., 2009. Le temple indien miroir du monde. Paris: Les Belles Lettres.
De Casparis, J.G., 1983. India and Maritime South East Asia: a Lasting Relationship. Third Sri Lanka Endowment Fund lecture, delivered at the University of Malaya on Wednesday, August 10, 1983, Kuala Lumpur, University of Malaya. Unpublished manuscript.

d'Errico, F., V. Roux \& Y. Dumond, 2000. Identification des techniques de finition des perles en calcédoine par l'analyse microscopique et rugosimétrique, in Cornaline de l'Inde: des pratiques techniques de Cambay aux techno-systèmes de l'Indus, ed. V. Roux. Paris: Maison des sciences de l'homme, 97-169.

Dikshit, K.N., 1954. Notes on some Indian amulets. Bulletin of Prince of Wales Museum 2, 86-99.

Dussubieux, L., 2001. L'apport de l'ablation laser couplée à l'ICP-MS à la charactérisation des verres: application à l'étude due verre archéologique de l'Océan Indien. Orleans: CNRS.

Dussubieux, L. \& B. Gratuze, 2010. Glass in Southeast Asia, in 50 Years of Archaeology in Southeast Asia: Essays in Honour of Ian Glover, eds. B. Bellina, T.O. Pryce \& J. Wisseman Christie. Bangkok: River Books, 244-57.

Dussubieux, L., B. Gratuze \& M. Blet-Lemarquand, 2010. Mineral soda alumina glass: occurence and meaning. Journal of Archaeological Science 37(7), 1646-55.

Earle, T.K., 1990. Style and iconography as legitimation in complex chiefdoms, in The Use of Style in Archaeology, eds. M. Conkey \& C. Hastorf. Cambridge: Cambridge University Press, 73-81.

Geertz, H., 1963. Indonesian cultures and communities, in Indonesia, ed. M. McVey. New Haven (CT): Yale University, HRAF, 24-96.

Gibson, J.J., 1979. The Ecological Approach to Perception, Erlbaum, London.

Gibson, J.J., 1986. The Ecological Approach to Visual Perception. Hillsdale (NJ): Lawrence Erlbaum Associates. [First published in 1979.]

Gill, S., J.-Y. Breuil, D. Allios \& V. Serdon, 2003. Mahasthangarh (Bangladesh) aux IIe-IIIe s. ap. J.-C.: céramiques estampées de signes de bon augure. Arts asiatiques 58, 60-72.

Gillis, J., 2012. The Human Shore: Seacoasts in History. Chicago (IL): University of Chicago Press.

Glover, I.C., 2000. State Formation in Early Southeast Asia: the Role of Exchange Networks with India and the Mediterranean World. Taejin City: Korea Chungnam National University

Glover, I.C., 2009. Sa Huynh-a sociocultural type. International Conference on 100 Years - Discovery and Research of Sa Huynh Culture, co-organized by Vietnam Institute of Culture and Arts Studies (Ministry of Culture, Sports and Tourism) and Department of Culture, Sport and Tourism of Quang Ngai province (Peoples Committee of Quang Ngai province), held from July 22, 2009 to July 24, 2009. Petrosetco Tower Hotel, Quang Ngai city, Quang Ngai, Vietnam. Unpublished manuscript.

Glover, I.C. \& B. Bellina, 2011. Ban Don Ta Phet and Khao Sam Kaeo: the earliest Indian contacts re-assessed, in Early Interactions between South and Southeast Asia: 
Reflections on Cross-cultural Exchange, eds. P.-Y. Manguin, A. Mani \& G. Wade. Singapore: SEAS, 17-46.

Hall, K.R., 1982. The Indianization of Funnan: an economic history of Southeast Asia's first state. Journal of Southeast Asian Studies 13(1), 81-106.

Hall, K.R., 1985. Maritime Trade and State Development in Early Southeast Asia. Honolulu (HI): University of Hawaii Press.

Hantman, J.L. \& S. Plog, 1982. The relationship of stylistic similarity to patterns of material exchange, in Contexts for Prehistoric Exchange, eds. J. Ericson \& T. Earle. New York (NY): Academic Press, 237-63.

Hendrickson, M., Q. Hua \& T.O. Pryce, in press. Using inslag charcoals as an indicator of terminal iron production within the Angkorian period (10th to 13th C. CE) centre of Preah Khan of Kompong Svay, Cambodia. Radiocarbon.

Higham, C.F.W., 2002. Early Cultures of Mainland Southeast Asia. Bangkok: River Books.

Higham, C.F.W. \& R. Thosarat, 2004. The Excavation of Khok Phanom Di, vol. VII: Summary and Conclusions. London: The Society of Antiquaries of London.

Hung, H.-C. \& P. Bellwood, 2010. Movement of raw materials and manufactured goods across the South China Sea after 500 всE: from Taiwan to Thailand, and back, in 50 Years of Archaeology in Southeast Asia: Essays in Honour of Ian Glover, eds. B. Bellina, E.A. Bacus, T.O. Pryce \& J. Wisseman Christie. Bangkok: River Books, 234-45.

Hung, H.-C., Y. Iizuka, P. Bellwood et al., 2007. Ancient jades map: 3,000 years of prehistoric exchange in Southeast Asia. Proceedings of the National Academy of Sciences 104(50), 19,745-50.

Hung, H.-C., K.D. Nguyen, P. Bellwood \& M.T. Carson, in press. Coastal connectivity: long-term trading networks across the South China Sea. Journal of Coastal and Island Archaeology.

Junker, L.L., 1990. Long Distance Trade and the Development of Socio-Political Complexity in Philippine Chiefdoms of the First Millennium to Mid Second Millennium AD. Unpublished PhD dissertation, Department of Anthropology, University of Michigan, Ann Arbor.

Junker, L.L., 1993. Crafts goods specialization and prestige goods exchange in the Philippine chiefdoms of the 15th and 16th centuries. Asian Perspectives 32(1), 1-35.

Junker, L. L., 1999. Raiding, Trading, and Feasting - the Political Economy of Philippine Chiefdoms. Honolulu (HI): University of Hawaii Press.

Jyotsna, M., 2000. Distinctive Beads in Ancient India = Amulets, Pendants, Eye-beads and Etched Beads from the Prehistoric to Medieval Periods. (British Archaeological Reports S864.) Oxford: Archaeopress.

Kim, N.C., L.V. Toi \& Trinh Hoang Hiep, 2010. Walls, warfare, and political centralization: recent sxcavations at Vietnam's ancient capital of Co Loa. Antiquity 84, 1011-27.

Kulke, H., 1990. Indian colonies, Indianization or cultural convergence? Reflections on the changing image of
Indias role in South-east Asia, in Onderzoek in ZuidoostAzie, ed. H. Schulte Nordholt. Leiden: Rijksuniversiteit te Leiden, 8-32.

Lemonnier, P. (ed.), 1993. Technological Choices: Transformation in Material Cultures Since the Neolithic. London: Routledge.

Mabbett, I.W., 1977. The Indianization of Southeast Asia. Journal of Southeast Asian Studies 8(1 \& 2), 1-14 \& 14361.

Mabbett, I.W., 1997. The Indianization of Mainland Southeast Asia: a reappraisal, in Living a Life in Accord with Dharma: Papers in Honour of Professor Jean Boisselier on his Eightieth Birthday, eds. N. Eilenberg, M.C.S. Diskul \& R.L. Brown. Bangkok: Silpakorn University, 342-55.

Malakie LaClair, J. \& A. Bevan, forthcoming. Spatial Analysis of an Early Port City, Khao Sam Kaeo: an Early Industrial Port City between the Indian Ocean and the South China Sea. Paris: Ecole française d'Extrême-Orient.

Malleret, L., 1959. L'archéologie du Delta du Mékong, part 1: l'exploration archéologique et les fouilles d'Oc-Ėo. Paris: Publication de L'École Française d'Extrême-Orient.

Malleret, L., 1960. L'archéologie du Delta du Mékong, part 2: La civilisation matérielle d'Oc-Èo. Paris: Publication de L'École Française d'Extrême-Orient, Paris.

Malleret, L., 1962. L'archéologie du Delta du Mékong, part 3: La culture du Founan. Paris: Publication de L'École Française d'Extrême-Orient.

Malleret, L., 1963. L'archéologie du Delta du Mékong, part 4: Le Cisbassac. Paris: Publication de L'École Française d'Extrême-Orient.

Manguin, P.-Y., 2000. City-states and City-state cultures in pre-15th century Southeast Asia, in A Comparative Study of Thirty City-State Cultures: an Investigation Conducted by the Copenhag Polis Centre, ed. M.H. Hansen. Copenhagen: C.A. Reitzels Forlag, 409-16.

Manguin, P.-Y., 2004. The archaeology of early maritime polities of Southeast Asia, in Southeast Asia: From Prehistory to History, eds. I.C. Glover \& P. Bellwood. London \& New York (NY): Routledge Curzon, 282313.

Manguin, P.-Y. \& I. Agustinjanto, 2006. The archaeology of Batujaya (West Java, Indonesia): an interim report, in Uncovering Southeast Asias Past: Selected Papers from the 10th International Conference of the European Association of Southeast Asian Archaeologists, eds. E. Bacus, I.C. Glover \& V. Piggott. Singapore: National University of Singapore Press, 245-57.

Manguin, P.-Y. \& I. Agustijanto, 2011. The Batujaya site: new evidence of early Indian influence in West Java, in Early Interactions between South and Southeast Asian: Reflections on Cross-cultural Exchange, eds. P.-Y. Manguin, A. Mani \& G. Wade. Singapore: ISEAS and Manohar, 113-36.

Manguin, P.-Y. \& V.S. Khai, 2000. Excavations at the Ba The Oc Eo complex (Vietnam): a preliminary report on the 1998 campaign, in Southeast Asian Archaeology 1998, eds. W. Lobo \& S. Riman. Hull: Centre of Southeast Asian Archaeology, 107-21. 
Manguin, P.-Y., A. Mani \& G. Wade (eds.), 2011. Early Interactions between South and Southeast Asia: Reflections on Cross-cultural Exchange. Singapore \& New Delhi: SEAS \& Manohar.

Marshall, J., 1951. Taxila: an Illustrated Account of the Archaeological Excavations. Cambridge: Cambridge University Press.

Murillo-Barroso, M., T.O. Pryce, B. Bellina \& M. MartinonTorres, 2010. Khao Sam Kaeo - an archaeometallurgical crossroads for trans-asiatic technological traditions. Journal of Archaeological Science 37, 1761-72

Nguyen, K.D., Trinh Can, Dan Van Thang, Vu Quoc Vien \& Nguyen Thi Hau, 1995. Ornaments from jar burial sites in Can Gio District, Ho Chi Minh City. Khao Co Hoc 1995(2), 27-46.

Peronnet, S., \& S. Srikanlaya, forthcoming. The Chineserelated ceramic at Khao Sam Kaeo, in Khao Sam Kaeo, an Early Port-City between the Indian Ocean and the South China Sea, ed. B. Bellina.

Pollock, S., 2000. Cosmopolitan and vernacular in history. Public Culture 12(3), 591-625.

Pollock, S.I., 2006. The Language of the Gods in the World of Men: Sanskrit, Culture, and Power in Premodern India. Berkeley (CA): University of California Press.

Pryce, T.O., B. Bellina-Pryce \& A. Bennett, 2008. The development of metal technologies in the Upper ThaiMalay Peninsula: initial interpretation of the archaeometallurgical evidence from Khao Sam Kaeo. Bulletin de L'Ecole Française d'Extrême-Orient 93, 295316.

Pryce, T.O., M. Brauns, N. Chang, E. Pernicka, M. Pollard et al., 2011. Isotopic and technological variation in prehistoric primary Southeast Asian copper production. Journal of Archaeological Sciences 38, 330922.

Pryce, T.O., M. Murillo, B. Bellina \& M. Martinón-Torres, in press. Khao Sam Kaeo - an archaeometallurgical crossroads for Trans-Asiatic technological traditions, in Proceedings of the 7th Beginnings of the Use of Metals and Alloys Conference, 13th to 17th September 2009, ed. S. Sharada. Bangalore, India.

Ray, H.P., 1994. The Winds of Change: Buddhism and the Maritime Links of Early South Asia. Delhi: Oxford University Press.

Reid, A., 1988. Southeast Asia in the Age of Commerce 14501680, vol. 1: The Lands Below the Winds. New Haven (CT) \& London: Yale University Press.

Reid, A., 2000. Negeri: the culture of Malay-speaking citystates of the fifteenth and sixteenth centuries, in $A$ Comparative Study of Thirty City-State Cultures: an Investigation Conducted by the Copenhagen Polis Centre, ed. M.H. Hansen. Copenhagen: C.A. Reitzels Forlag, 417-29.

Reinecke, A. \& N.T.T. Luyen, 2009. Recent discoveries in Vietnam: gold masks and other precious items. Arts of Asia 39, 58-67.
Roux, V. (ed.), 2000. Cornaline de l'Inde: des pratiques techniques de Cambay aux techno-systèmes de l'Indus. Paris: Editions de la Maison des Sciences de l'Homme.

Smail, J., 1962. On the possibility of an autonomous history of Southeast Asia. Journal of Southeast Asian Studies 2(2), 72-102.

Smith, M., 1999. Indianisation from the Indian point of view: trade and cultural contacts with Southeast Asia in the early first millennium CE. Journal of the Economic and Social History of the Orient 42(1), 1-26.

Solheim, W.G., 1984. Remarks on the lingling-O and bicephalous ornaments. Journal of the Hong Kong Archaeological Society 10 (1982-83), 107-11.

Solheim, W.G., 2000. Taiwan, coastal South China and northern Vietnam and the Nusantao maritime trading network. Journal of East Asian Archaeology 2(1-2), 273-84.

Solheim, W.G., 2006. Archaeology and Culture in Southeast Asia: Unravelling the Nusantao, with contributions from D. Bulbeck \& A. Flavel. Quezon City: The University of the Philippines Press.

Southworth, W.A., 2004. The coastal states of Champa, in Southeast Asia, from the Prehistory to History, eds. I.C. Glover \& P. Bellwood. London: Routledge, Curzon Press, 209-33.

Stark, M., 1998. The transition to history in the Mekong Delta: a view from Cambodia. International Journal of Historic Archaeology 2(3), 175-204.

Stark, M., 2006. Pre-Angkorian settlement trends in Cambodia's Mekong Delta and the Lower Mekong Archaeological Project. Bulletin of the Indo-Pacific Prehistory Association 26, 98-109.

Stark, M.T. \& B. Souath, 2001. Recent research on Early Historic States in Cambodia's Lower Mekong Delta. Bulletin of the Indo-Pacific Prehistory Association 17, 85-98.

Stark, M.T., P.B. Griffin, Chuch Phoeurn, J. Ledgerwood et al., 1999. Results of the 1995-1996 field investigations at Angkor Borei, Cambodia. Asian Perspectives 38(1), 736 .

Stoffregen, T.A., 2000. Affordances and events. Ecological Psychology 12(1), 1-28.

Theunissen, R., 2007. The agate and carnelian ornaments, in The Excavations of Noen U-Loke and Non Muang Kao, eds. C. Higham, A. Kijngam \& S. Talbot. Bangkok: The Thai Fine Arts Department, 359-77.

Theunissen, R., P. Grave \& G. Bailey 2000. Doubts on diffusion: challenging the assumed Indian origin of Iron Age agate and carnelian beads in Southeast Asia. World Archaeology 32, 84-105.

Veraprasert, M., 1992. Khlkong Thom: an ancient bead manufacturing locations and an ancient entrepôt, in Early Metallurgy, Trade and Urban Centres in Thailand and Southeast Asia, eds. I.C. Glover, P. Suchitta \& J. Villiers. Bangkok: White Lotus, 149-61.

Vickery, M., 1998. Society, Economics, and Politics in PreAngkor Cambodia: the 7th-8th Centuries. Tokyo, The Centre for East Asian Cultural Studies for Unesco, the Toyo Bunko. 
Wheatley, P., 1983. Nagara and Commandery: Origins of Southeast Asian Urban Traditions. Chicago (IL): Department of Geography.

Wisseman Christie, J., 1984/5. Trade and early state formation in maritime Southeast Asia: Kedah and Srivijaya. Jabat 13, 43-56.

Wisseman Christie, J., 1990. Trade and state formation in the Malay Peninsula and Sumatra, 300 BC-AD 700, in The Southeast Asian Port and Polity: Rise and Demise, eds. J. Kathirithamby-Wells \& J. Villiers. Singapore: Singapore University Press, 39-60.

Wisseman Christie, J., 1995. State formation in Early Maritime Southeast Asia: a consideration of the theories and the data. Bijdragen tot de Taal-, Land-en Volkenkunde 151(2), 235-88.

Wobst, H.M., 1977. Stylistic behavior and information exchange, in For the Director: Research Essays in Honor of James B. Griffen, ed. E.H. Cleland. (Anthropological Papers.) Ann Arbor (MI): University of Michigan, Museum of Anthropology, 317-42.

Wolters, O.W., 1982. History, Culture and Religion in Southeast Asian Perspectives. Singapore: Institute of Southeast Asian Studies.

Wolters, O.W., 1999. History, Culture, and Region in Southeast Asian Perspectives. New York (NY) \& Singapore: Southeast Asia Program, Cornell University, Ithaca, New York.
Wynne-Jones, S. \& B.B.B. Mapunda, 2008. This is what pots look like here: ceramics, traition and consumption on Mafia Island, Tanzania. Azania: Archaeological Research in Africa 43, 1-17.

Yamagata, M., 1997. Formation of Lin Yi; derived from archaeological materials. Journal of Southeast Asian Archaeology 17(6), 168-84.

Yamagata, M., 2007. The early history of Lin-i viewed from archaeology. Acta Asiatica 92, 1-30.

Yamagata, M. \& I.C. Glover, 1994. Excavations at Buu Chau Hill, Tra Kieu, Vietnam 1993. The Journal of Southeast Asian Archaeology 14, 48-57.

\section{Author biography}

Dr Bérénice Bellina's research focus is the trade and cultural exchange process in the Indian Ocean and more especially between South and Southeast Asia. She uses the technological analysis of industries as a means to comprehend social and political processes in order to reconstruct the impact of trade on ethnicity and identity construction. Since 2005, she has been the co-director of the Thai-French Archaeological Mission in Upper Thai-Malay Peninsula that investigates the co-evolution of the different populations and ecosystems in relation to long-distance trade from the prehistoric period to the late first millennium $\mathrm{AD}$. 